\title{
New Records of Antarctic Tardigrada with Comments on Interpopulation Variability of the Paramacrobiotus fairbanksi Schill, Förster, Dandekar and Wolf, 2010
}

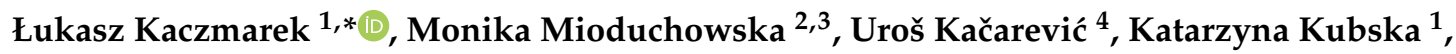 \\ Ivan Parnikoza ${ }^{5,6}$, Bartłomiej Gołdyn ${ }^{7}$ (D) and Milena Roszkowska ${ }^{1,8}$ \\ 1 Department of Animal Taxonomy and Ecology, Faculty of Biology, Adam Mickiewicz University, Poznań, \\ Uniwersytetu Poznańskiego 6, 61-614 Poznań, Poland; katarzyna.qbska@gmail.com (K.K.); \\ mil.roszkowska@gmail.com (M.R.) \\ 2 Department of Genetics and Biosystematics, Faculty of Biology, University of Gdańsk, Gdańsk, \\ Wita Stwosza 59, 80-308 Gdańsk, Poland; monika.mioduchowska@biol.ug.edu.pl \\ 3 Department of Marine Plankton Research, Institute of Oceanography, University of Gdansk, Marszałka \\ Piłsudskiego 46, 81-378 Gdynia, Poland \\ 4 Department of Morphology, Systematics and Phylogeny of Animals, Faculty of Biology, University of \\ Belgrade, Studentski trg 16, 11000 Belgrade,Serbia; m81_2015@stud.bio.bg.ac.rs \\ 5 National Antarctic Scientific Center of Ukraine, Boulevard Tarasa Shevchenka 16, 01601 Kyiv, Ukraine; \\ ivan.parnikoza@gmail.com \\ 6 Institute of Molecular Biology and Genetics of National Academy of Science of Ukraine, Kyiv, Ukraine, \\ st. Acad. Zabolotny, 150, Kyiv 03143, Ukraine \\ 7 Department of General Zoology, Faculty of Biology, Adam Mickiewicz University, \\ Uniwersytetu Poznańskiego 6, 61-614 Poznań, Poland; glodny@amu.edu.pl \\ 8 Department of Bioenergetics, Faculty of Biology, Adam Mickiewicz University, Poznan, \\ Uniwersytetu Poznańskiego 6, 61-614 Poznań, Poland \\ * Correspondence: kaczmar@amu.edu.pl
}

Received: 19 February 2020; Accepted: 16 March 2020; Published: 20 March 2020

\begin{abstract}
Studies on Antarctic tardigrades started at the beginning of the twentieth century and have progressed very slowly and ca. 75 tardigrade species are known from this region. Paramacrobiotus fairbanksi was described from USA based on genetic markers and later reported from Italy, Poland, and Spain. The "everything is everywhere" hypothesis suggests that microscopic organisms have specific features which help them to inhabit most of environments and due to this they can be considered cosmopolitan. In the present paper, we report eight tardigrade taxa from Antarctic, including the first report of Pam. fairbanksi from Southern Hemisphere, which could suggest that the "everything is everywhere" hypothesis could be true, at least for some tardigrade species. Moreover, we also genetically and morphologically compare a few different populations of Pam. fairbanksi. The p-distances between COI haplotypes of all sequenced Pam. fairbanksi populations from Antarctica, Italy, Spain, USA and Poland ranged from $0.002 \%$ to $0.005 \%$. In the case of COI polymorphism analyses, only one haplotype was observed in populations from Antarctica, USA and Poland, two haplotypes were found in population from Spain, and six haplotypes were observed in population from Italy. We also found some statistically significant morphometrical differences between the populations of Pam. fairbanksi from different regions and designed a new specific primers for Paramacrobiotus taxa.
\end{abstract}

Keywords: cosmopolitism; dispersal; zoogeography; "everything is everywhere" hypothesis, fauna; water bears 


\section{Introduction}

Antarctic is the coldest and most extreme region on the planet with the lack of surface liquid freshwater. Continental Antarctic with an area of ca. 14 million square kilometers has only ca. $0.3 \%$ ice-free lands. The entire continent is divided into three main units, i.e., East Antarctica, West Antarctica, and the Antarctic Peninsula [1]. Our knowledge of micro-invertebrates in this region is patchy and fragmented, because most studies have focused on easily accessible regions that are close to research stations [2]. Many of Antarctic invertebrates are endemic, some of them have a continental distribution, others are restricted only to maritime Antarctic and only a few can be characterized as pan-Antarctic species such as eutardigrade Acutuncus antarcticus (Richters [3]) e.g., [4,5].

The phylum tardigrada currently consists of ca. 1300 species [6-9] that inhabit terrestrial and aquatic environments throughout the world $[10,11]$.

Studies on Antarctic tardigrades started at the beginning of the twentieth century and have progressed very slowly until now. Currently, ca. 75 tardigrade species have been reported from continental Antarctic and few from other regions (for review see [12] and later publications [2,13-24]).

Paramacrobiotus fairbanksi was described by Schill, Förster, Dandekar and Wolf [25] from Alaska (USA), based on genetic differences from other members of the genus Paramacrobiotus. It was later reported from Italy, Poland, and Spain [26-28]. Moreover, specimens reported by Guidetti et al. [29] from Italy as Macrobiotus richtersi and Murray [30] were also attributed to Pam. fairbanksi based on genetic markers [28].

According to the "everything is everywhere" hypothesis it is assumed that microorganisms and small invertebrates have cosmopolitan ranges. This hypothesis was introduced at the beginning of the 20th century [31,32]. Due to the presence of certain features in microscopic organisms that are not found in larger animals, they can inhabit most environments and are considered to be cosmopolitan species. Among the most frequently mentioned adaptations are the possibility of quite ease passive dispersion (through wind, sea currents, water, other animals, etc.), the presence of very resistant spore stages (which include, for example, cysts, eggs, or cryptobiotic individuals) that help to survive extreme conditions and maintain in any environment, as well as the presence of asexual or parthenogenetic reproduction that allows a rapid increase in the number of individuals e.g., [32-36]. However, the cosmopolitanism of microscopic organisms is increasingly discussed and undermined also within tardigrades e.g., [37-39]. Gasiorek et al. [40] provided a first Australasian, molecularly verified record of a heterotardigrade species Echiniscus testudo (Doyère [41]) originally described from Holarctic (Europe, France) which could suggest agreement with the hypothesis "everything is everywhere" for tardigrades.

In this paper we report eight tardigrade taxa from Antarctic including the first report of Pam. fairbanksi from the Southern Hemisphere which is another strong argument suggesting that "everything is everywhere" hypothesis could be true, at least for some tardigrade species. Moreover, we also genetically and morphologically compare a few different populations of Pam. fairbanksi, and designed a new specific primers for Paramacrobiotus taxa.

\section{Materials and Methods}

\subsection{Sample Processing}

Eleven moss-lichen and algae samples from soil, rocks, and freshwater sediments were collected during the 5th (2012-2013), 7th (2014-2015) and 9th (2016-2017) Belarusian Antarctic Expeditions (BAE) near the Belarusian Antarctic Station "Vechernia" and Russian Station "Progress" (for details see Table 1). The samples were packed in paper envelopes, dried at a room temperature and delivered to the laboratory at the Faculty of Biology, Adam Mickiewicz University, Poznań, Poland. Tardigrades were extracted from the samples and studied following the protocol of Stec et al. [42]. 
Table 1. Samples and localities.

\begin{tabular}{cccc}
\hline No & Coordinates & Sample Description & Expedition \\
\hline 1 & $67^{\circ} 39^{\prime} \mathrm{S}, 46^{\circ} 09^{\prime} \mathrm{E}$ & Vechernia Mt Base, lichen Usnea sphacelata. & 9 BAE (2016-2017) \\
2 & $67^{\circ} 39^{\prime} \mathrm{S}, 46^{\circ} 09^{\prime} \mathrm{E}$ & Vechernia Mt Base, lichen Umbilicaria aprina. & 9 BAE (2016-2017) \\
3 & $69^{\circ} 24^{\prime} \mathrm{S}, 76^{\circ} 24^{\prime} \mathrm{E}$ & Progress Base, lichen Umbilicaria decussata. & 9 BAE (2016-2017) \\
4 & $67^{\circ} 39^{\prime} \mathrm{S}, 46^{\circ} 09^{\prime} \mathrm{E}$ & Vechernia Mt Base, lichen Xanthoria elegans. & 9 BAE (2016-2017) \\
5 & $67^{\circ} 39^{\prime} \mathrm{S}, 46^{\circ} 09^{\prime} \mathrm{E}$ & Vechernia Mt Base, algae-bacterial mat from Nizhne Lake. & 7 BAE (2014-2015) \\
6 & $70^{\circ} 46^{\prime} \mathrm{S}, 11^{\circ} 49^{\prime} \mathrm{E}$ & Vechernia Mt Base, algae-bacterial mat from Nizhne Lake. & 5 BAE (2012-2013) \\
7 & $67^{\circ} 39^{\prime} \mathrm{S}, 46^{\circ} 09^{\prime} \mathrm{E}$ & Vechernia Mt Base, moss Ceratodon purpureus. & 7 BAE (2014-2015) \\
8 & $69^{\circ} 24^{\prime} \mathrm{S}, 76^{\circ} 24^{\prime} \mathrm{E}$ & Progress Base, malanized soil surface algae. & 9 BAE (2016-2017) \\
9 & $69^{\circ} 23^{\prime} \mathrm{S}, 76^{\circ} 23^{\prime} \mathrm{E}$ & Progress Base, algae Parsiola crispa. & 9 BAE (2016-2017) \\
10 & $69^{\circ} 22^{\prime} \mathrm{S}, 76^{\circ} 23^{\prime} \mathrm{E}$ & Progress Base, sediment from bottom of the snow collector for & 9 BAE (2016-2017) \\
11 & $67^{\circ} 39^{\prime} \mathrm{S}, 46^{\circ} 09^{\prime} \mathrm{E}$ & fresh-water maker. & 9 BAE (2016-2017) \\
\hline
\end{tabular}

\subsection{Microscopy, Morphometrics, and Morphological Nomenclature}

Specimens for light microscopy were mounted on microscope slides in a small drop of Hoyer's medium, prepared according to Ramazzotti and Maucci [10] as in the English translation by Beasley [43], and secured with a cover slip. Then, the slides were placed in an incubator and dried for two days at ca. $60{ }^{\circ} \mathrm{C}$. Dried slides were sealed with a transparent nail polish and examined under an Olympus BX41.

All measurements are given in micrometers $[\mu \mathrm{m}]$. Structures were measured only if their orientation was suitable. Body length was measured from the anterior extremity to the end of the body, excluding the hind legs. The types of bucco-pharyngeal apparatuses and claws were classified according to Pilato and Binda [44]. Buccal tubes, claws, and eggs were measured according to Kaczmarek and Michalczyk [45]. Macroplacoid length sequence was given according to Kaczmarek et al. [46]. The $p t$ ratio is the ratio of the length of a given structure to the length of the buccal tube, expressed as a percentage [47]. The $p t$ values are always provided in italics.

Morphometric data were handled using the "Parachela" ver. 1.7 template available from the Tardigrada Register [48]. Tardigrade taxonomy follows Bertolani et al. [49]. Genus abbreviations follow Perry et al. [50].

The map and figures were assembled in Corel Photo-Paint 2017.

\subsection{Comparative Material}

Species were identified based on original descriptions [3,15,25,51,52] and later partial redescriptions [53,54]. The type material (paratypes) of Dastychius improvisus (Dastych [52]) and Mesobiotus blocki (Dastych [52]) from the collection of Zoologisches Museum of Hamburg (Germany) were examined. Specimens of Pam. fairbanksi from type locality and additional material from Italy from the Roberto Guidetii collection (University of Modena and Reggio Emilia, Modena, Italy) were also used in analysis, altogether with specimens of Pam. fairbanksi from the laboratory culture conducted at the Department of Animal Taxonomy and Ecology (Adam Mickiewicz University in Poznań, Poland). Specimens of Pam. fairbanksi (Pam.fai_I_PL.018) (5003'44" N, 1957'26" E, 205 m asl: Jagiellonian University Botanical Garden, Kopernika 27, Kraków, Poland; moss on a tree; 03.2014; coll. Piotr Gasiorek) were cultured in small Petri dishes in spring water mixed with distilled water (3:1) with the rotifers and nematodes added as a food ad libitum. Cultures were kept in an environmental chamber with a temperature at $18{ }^{\circ} \mathrm{C}$ and in the darkness.

\subsection{DNA Extraction and Genotyping}

Four specimens and 31 eggs of Pam. fairbanksi were identified (partially based on [25]) in vivo using light microscopy (LM) prior to DNA extraction for genotyping analysis. Eggs were divided into three samples. Ten eggs were placed in two of them and eleven eggs in the last sample. Genomic DNA of adult individuals was extracted using a Chelex®100 resin (Bio-Rad, Warsaw, Poland) extraction 
method described by Casquet et al. [55] with a modified protocol included in Stec et al. [42]. In turn, genomic DNA from eggs was extracted using silica membranes from the commercial Genomic Mini kit (A\&A Biotechnology, Gdynia, Poland).

Three DNA fragments differing in effective mutation rates were sequenced as follows: two conservative nuclear ribosomal subunit genes, i.e., $18 \mathrm{~S}$ rRNA and $28 \mathrm{~S}$ rRNA, and protein coding mitochondrial COI barcode gene with an intermediate effective mutation rate. Regions of the nuclear ribosomal subunit genes $18 \mathrm{~S}$ and $28 \mathrm{~S}$ were amplified using the following primers: SSU01_F (5'-AACCTGGTTGATCCTGCCAGT-3') and SSU82_R (5'-TGATCCTTCTGCAGGTTCACCTAC$3^{\prime}$, [56]) for the 18S rRNA gene fragment; 28SF0001 (5'-ACCCvCynAATTTAAGCATAT-3') and 28SR0 990 (5'-CCTTGGTCCGTGTTTCAAGAC-3'; [57]) for the 28S rRNA gene fragment. In turn, the COI gene fragment was amplified using universal primers: HCO2198 (5'-TAAACTTCAGGGTGACCAAA AAATCA-3') and LCO1490 (5'-GGTCAACAAATCATAAAGATATTGG-3', [58]). All barcode sequences were obtained only from DNA extracted from eggs and it was problematic in the case of adult individuals. To overcome this problem, the obtained COI sequences were further used to design internal primers to amplify a $392 \mathrm{bp}$ fragment with the Primer3 v. 0.4.0 [59] software package. The sequence of the newly developed forward ParCOIF primer was 5'-GGGTCYCCHCCHCCBGCKGGRTCA-3', and that of the reverse ParCOIR was 5'-GGRGCYCCHGATATRGCHTTYCCHCG-3'.

All the polymerase chain reactions were carried out in $20 \mu \mathrm{L}$ volume containing $0.8 \times$ JumpStart Taq ReadyMix (1 U of JumpStart Taq DNA polymerase, $4 \mathrm{mM}$ Tris- $\mathrm{HCl}$ (pH 8.3), $20 \mathrm{mM} \mathrm{KCl}, 0.6 \mathrm{mM}$ $\mathrm{MgCl}_{2}, 0.08 \mathrm{mM}$ of dNTP; Sigma-Aldrich, Darmstadt, Germany), $0.4 \mu \mathrm{M}$ of proper forward and reverse primers and $c a .1 \mathrm{ng}$ of DNA. The PCR reactions were performed in a BiometraTProfessional thermocycler. The PCR cycling profile to amplify the $18 \mathrm{~S}$ rRNA gene fragment was as follows: initial denaturation at $95^{\circ} \mathrm{C}$ for $5 \mathrm{~min}$ followed by 40 cycles of $95^{\circ} \mathrm{C}$ for $30 \mathrm{~s}, 55^{\circ} \mathrm{C}$ for $40 \mathrm{~s}$, and $72{ }^{\circ} \mathrm{C}$ for $1 \mathrm{~min} 30 \mathrm{~s}$, and ending with $72{ }^{\circ} \mathrm{C}$ for $4 \mathrm{~min}$. The $28 \mathrm{~S}$ rRNA gene fragment was amplified under conditions described by Mironov et al. [57]. The PCR protocol for the amplification of the COI gene fragment using $\mathrm{HCO} 2198$ and LCO1490 primers was as follows: initial denaturation at $94{ }^{\circ} \mathrm{C}$ for $5 \mathrm{~min}$ followed by 35 cycles of $94{ }^{\circ} \mathrm{C}$ for $30 \mathrm{~s}, 45^{\circ} \mathrm{C}$ for $1 \mathrm{~min}$, and $72{ }^{\circ} \mathrm{C}$ for $1 \mathrm{~min}$, and ending with $72{ }^{\circ} \mathrm{C}$ for $5 \mathrm{~min}$. In turn, amplification of the COI gene fragment using the newly designed degenerate primers was performed under the following conditions: initial denaturation at $95^{\circ} \mathrm{C}$ for $5 \mathrm{~min}$ followed by 44 cycles of $95^{\circ} \mathrm{C}$ for $30 \mathrm{~s}, 51.5^{\circ} \mathrm{C}$ for $40 \mathrm{~s}$, and $72{ }^{\circ} \mathrm{C}$ for $1 \mathrm{~min}$, and ending with $72{ }^{\circ} \mathrm{C}$ for $5 \mathrm{~min}$.

Amplified PCR products were separated in 1\% agarose gel in a $1 \times$ SB buffer and visualized under UV light using Midori Green Advance DNA Stain (Genetics). Exonuclease I (20 U/ $\mu \mathrm{L}$, Thermo Scientific) and alkaline phosphatase FastAP (1 U/ $\mu \mathrm{L}$, Thermo Scientific, Waltham, MA, USA) were applied to clean the PCR products. Sequencing directly in both directions was performed using the BigDyeTM terminator cycle sequencing method and ABI Prism 3130xl genetic analyzer (Life Technologies, Carlsbad, CA, USA).

\subsection{Comparative Molecular Analysis}

BLAST (Basic Local Alignment Search Tool; [60]) searches at NCBI were performed to verify the identity and homology of the amplified nuclear and mitochondrial barcode sequences. All sequences obtained in our study and described by Guidetti et al. [28] as originated from Pam. fairbanksi, were then aligned using the ClustalW Multiple Alignment tool [61] implemented in BioEdit v. 7.2 .5 [62]. Alignment sequences were trimmed to 822 and $574 \mathrm{bp}$ for $18 \mathrm{~S}$ rRNA and COI barcodes (only obtained from eggs), respectively. Calculation for the uncorrected pairwise distances (p-distances) was performed for COI sequences using the MEGA $X$.

The COI sequences were translated into amino acid sequences using the EMBOSS-TRANSEQ application $[63,64]$ to check for indels and internal stop codons. The COI haplotypes were retrieved using DnaSP v5.10.01 software [65]. 
All obtained sequences have been deposited in GenBank under the following accession numbers: COI (primers: HCO2198 and LCO1490), MN964281-MN964282; COI (primers: ParCOIF and ParCOIR), MN961616; 18S rRNA, MN960302-MN960304; 28S rRNA, MN960306-MN960307.

\subsection{Statistical Analysis}

Statistical significance of the differences in morphometrics between the studied populations of Pam. fairbanksi was analyzed using the analysis of variance (ANOVA) test with Bonferroni correction for multiple comparisons. Measurements of the body and buccal tube length (BL and BTL) were used as dependent and populations as grouping variable. Shapiro test was used to check for normality of distribution in residuals resulting from these models.

Apart from the BL and BTL measurements, we also analyzed the overall differences in morphometrics of other measured traits: stylet support insertion points (SSIP), external width of buccal tube (BTEW), and placoids (M1, macroplacoid 1; M2, macroplacoid 2; M3, macroplacoid 3; Mi, microplacoid; MR, macroplacoid row; PR, placoid row). We performed principal component analysis (PCA) on these measurements (the PCA input data matrix was tardigrade specimens $\times$ characters length), and then used the resulting first component as the dependent variable in ANOVA, with populations as grouping variable and Bonferroni correction. Later, to compare the differences in proportions of the same characters, the same analyses were performed for the $p t$ ratios of exact characters. Measurements of 44 tardigrade specimens were used in the analyses, including 16 Antarctic, 15 Polish, 9 Alaskan, and 4 Italian. In case some of the measurements were missing they were replaced by mean values.

ANOVA was also used to test for the differences in egg morphology between the populations studied. To do so, for each obtained egg its bare diameter (EBD), full diameter (EFD), and processes height $(\mathrm{PH})$ were measured and used as dependent variable in the models, again with population as the variable determining compared groups and Bonferroni correction. Measurements of 49 tardigrade eggs were used in the analyses, including 18 Alaskan, 16 Antarctic, and 15 Polish. In case some of the measurements were missing they were replaced by mean values. All the analyses were performed in $\mathrm{R}$ 3.4.4. We considered $p<0.05$ as a level determining statistical significance; in case of post hoc tests only statistically significant results are presented.

\section{Results}

\subsection{Species Found}

In eight of eleven samples, 461 tardigrades, 102 exuviae and 127 eggs belonging to eight taxa were found, i.e., Acu. antarcticus; Barbaria pseudowendti (Dastych [52]); Das. improvisus; Hebesuncus mollispinus Pilato, McInnes and Lisi [15]; Mes. blocki; Mesobiotus sp.; Milnesium quadrifidum Nederström [51] (Figure 1); and Pam. fairbanksi (Figures 2 and 3) (for more details see Table 2). 

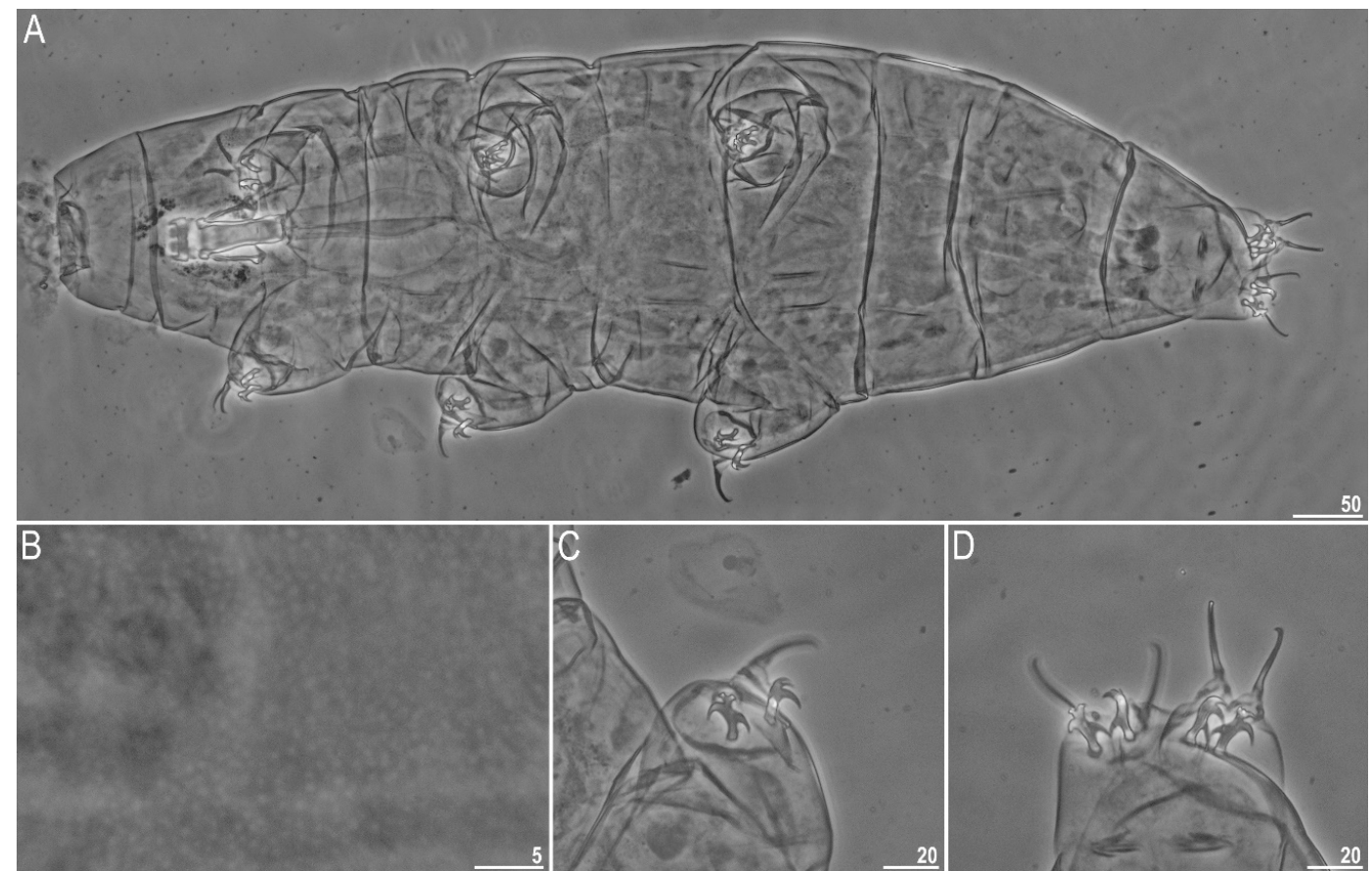

Figure 1. Milnesium quadrifidum. (A) Dorso-ventral projection of the entire animal; (B) Pseudopores visible on the dorsal side of the body; (C) Claws II; (D) Claws IV. Scale bars in ( $\mu \mathrm{m}$ ). All PCM (Phase Contrast Microscopy).

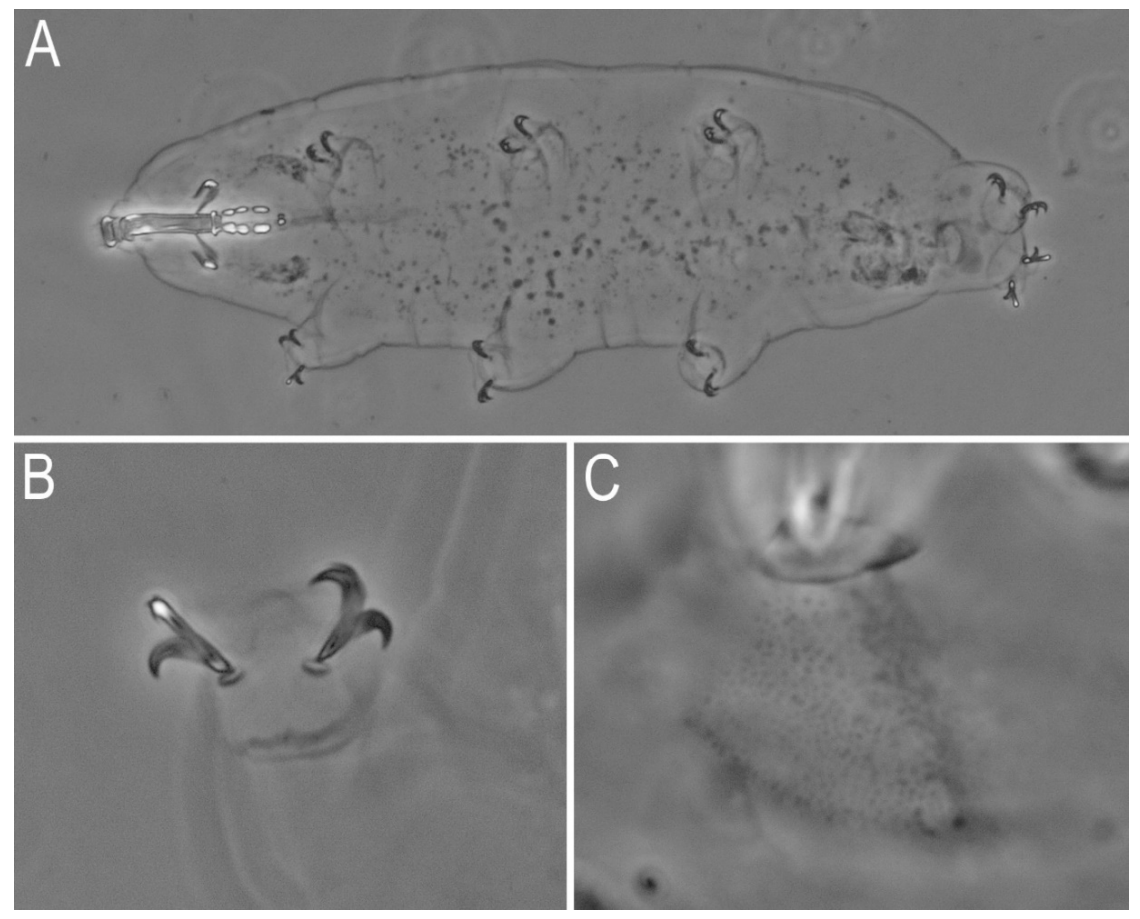

Figure 2. Paramacrobiotus fairbanksi (Polish population). (A) Dorso-ventral projection of the entire animal; (B) Claws I with smooth lunules; (C) Granulation on leg IV with visible smooth lunulae. Scale bars in $(\mu \mathrm{m})$. All PCM. 

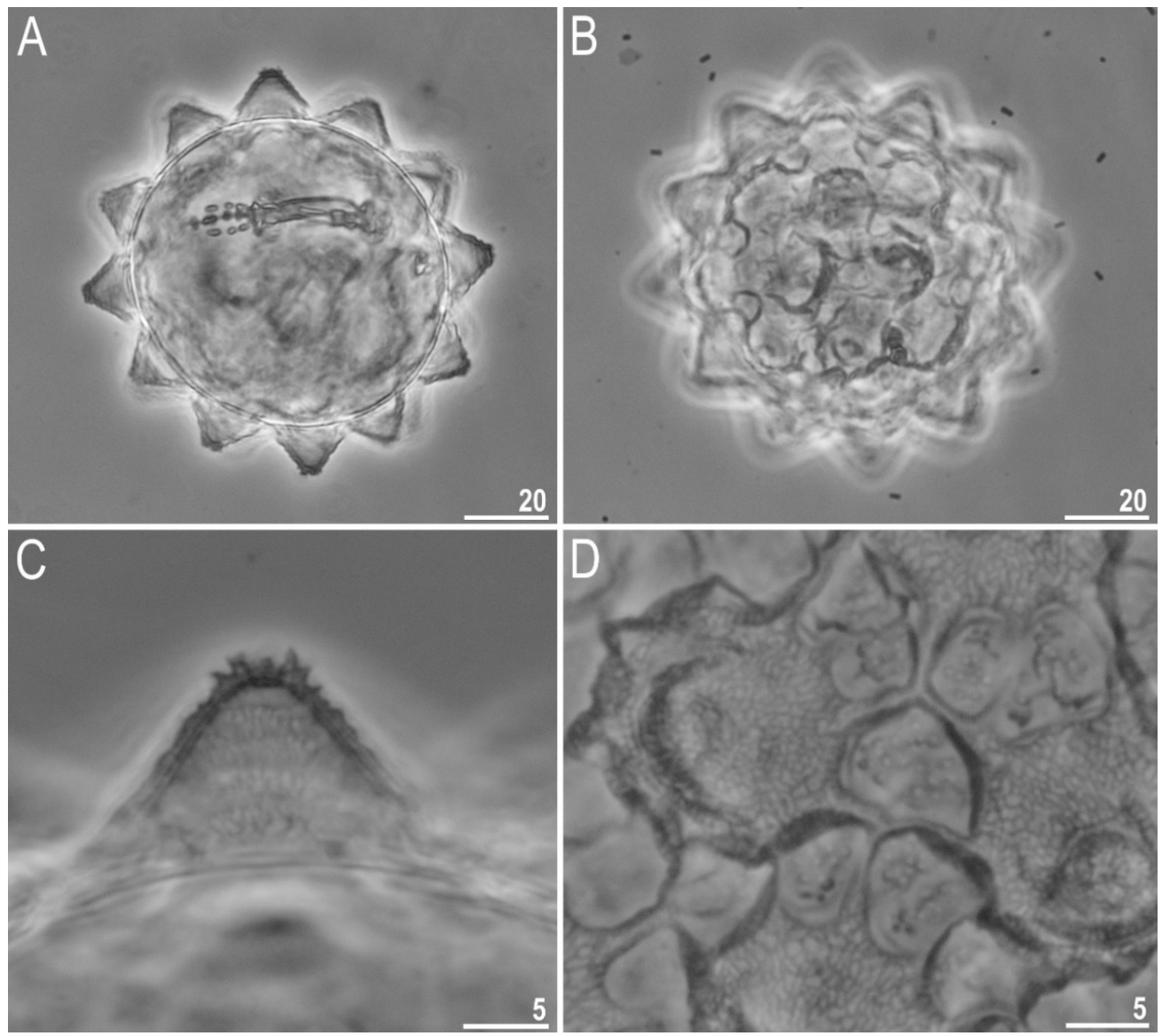

Figure 3. Paramacrobiotus fairbanksi (Polish population). (A,B) Egg chorion; (C) Egg process morphology; (D) The surface between egg processes with visible areoles. Scale bars in $(\mu \mathrm{m})$. All PCM.

Table 2. Species list with their localities and remarks (exuvia not included; s/s + e, samples no/no specimens + eggs.

\begin{tabular}{|c|c|c|}
\hline Taxon & $\mathrm{s} / \mathrm{s}+\mathrm{e}$ & Remarks \\
\hline Acu. antarcticus & $1,8 / 59$, & Pan-Antarctic species [5] \\
\hline Bar. pseudowendti (Dast) & $1 / 53,2 / 3,4 / 1$ & Endemic species known only from Antarctica [52] \\
\hline Das. improvisus (Dastych [52]) & $2 / 9$ & $\begin{array}{l}\text { Species of the monotypic genus endemic for Antarctica This is a } \\
\text { second report of this species [52] }\end{array}$ \\
\hline Heb. mollispinus Pilato et al. [15] & $2 / 50,4 / 4,7 / 19$ & Species known only from Antarctica and South America $[15,66]$ \\
\hline Mes. blocki (Das & $7 / 25$ & $\begin{array}{l}\text { Endemic species known only from Antarctica [52]. This is second } \\
\text { report of this species }\end{array}$ \\
\hline $\begin{array}{l}\text { Mesobiotus sp. } \\
\text { Mil. quadrifidum Nederström [51] }\end{array}$ & $\begin{array}{l}3 / 4,2 / 2 \\
2 / 1\end{array}$ & $\begin{array}{l}\text { Undefined species due to lack of eggs in the examined samples } \\
\text { Species with unclear taxonomic position [27] }\end{array}$ \\
\hline Pam. fairbanksi Schill et al. [25] & $7 / 25+59$ & $\begin{array}{l}\text { Probably cosmopolitan species up to now reported from Italy, } \\
\text { Poland, Spain, USA (Alaska; type locality) [25-29] }\end{array}$ \\
\hline
\end{tabular}

\subsection{Morphometric Comparison of Different Populations of the Pam. fairbanksi}

Significant differences in BL between the studied populations (Tables 3-10 and Figures 4-12) were found ( $\mathrm{df}=3, \mathrm{~F}=4.184, p=0.0115, \mathrm{n}=44)$, with specimens from Antarctic being significantly longer than the ones from Poland $(p=0.013$, Figure 4$)$. Similarly, the model with the first PCA component from the measurements of all the studied morphological characters as the dependent variable $(\mathrm{df}=3, \mathrm{~F}=4.721 ; p=0.0065 ; \mathrm{n}=44)$ showed differences between Polish and Antarctic $(p=$ 0.013 ) populations (Figure 5). ANOVA performed for BTL ( $\mathrm{df}=3, \mathrm{~F}=5.741, p=0.0023, \mathrm{n}=44$ ) also showed differences between Polish and Antarctic $(p=0.072)$, as well as Polish and Alaskan $(p=0.0115)$ populations (Figure 6). Analysis for SSIP lengths ( $\mathrm{df}=3, \mathrm{~F}=6.156, p=0.0015, \mathrm{n}=44)$ showed the 
same tendency; SSIP in Polish populations was significantly smaller than in Antarctic $(p=0.0037)$ and Alaskan $(p=0.0126)$ (Figure 7).

The $p t$ of BL also differed between the populations ( $\mathrm{df}=3, \mathrm{~F}=5.371, p=0.0034, \mathrm{n}=44)$, with specimens from Alaska having significantly lower $p t$ of BL than those from Antarctic $(p=0.0029$, Figure 8). Similar differences $(p=0.0021)$ between the two populations were found when first component of PCA for $p t$ of all the measurements was analyzed $(\mathrm{df}=3, \mathrm{~F}=6.332, p=0.0013, \mathrm{n}=44)$, with additional significant differences between Alaskan and Italian populations ( $p=0.019$, Figure 9 ). ANOVA performed for $p t$ of SSIP showed no significant differences between the populations $(\mathrm{df}=3$, $\mathrm{F}=1.196, p=0.324, \mathrm{n}=44$ ).

Table 3. Measurements (in $\mu \mathrm{m}$ ) and $p t$ values of selected morphological structures of individuals of the Antarctic population of Paramacrobiotus fairbanksi Schill, Förster, Dandekar and Wolf [25] mounted in Hoyer's medium (N, number of specimens/structures measured; RANGE refers to the smallest and the largest structure among all measured specimens; SD, standard deviation; $p t$, ratio of the length of a given structure to the length of the buccal tube expressed as a percentage).

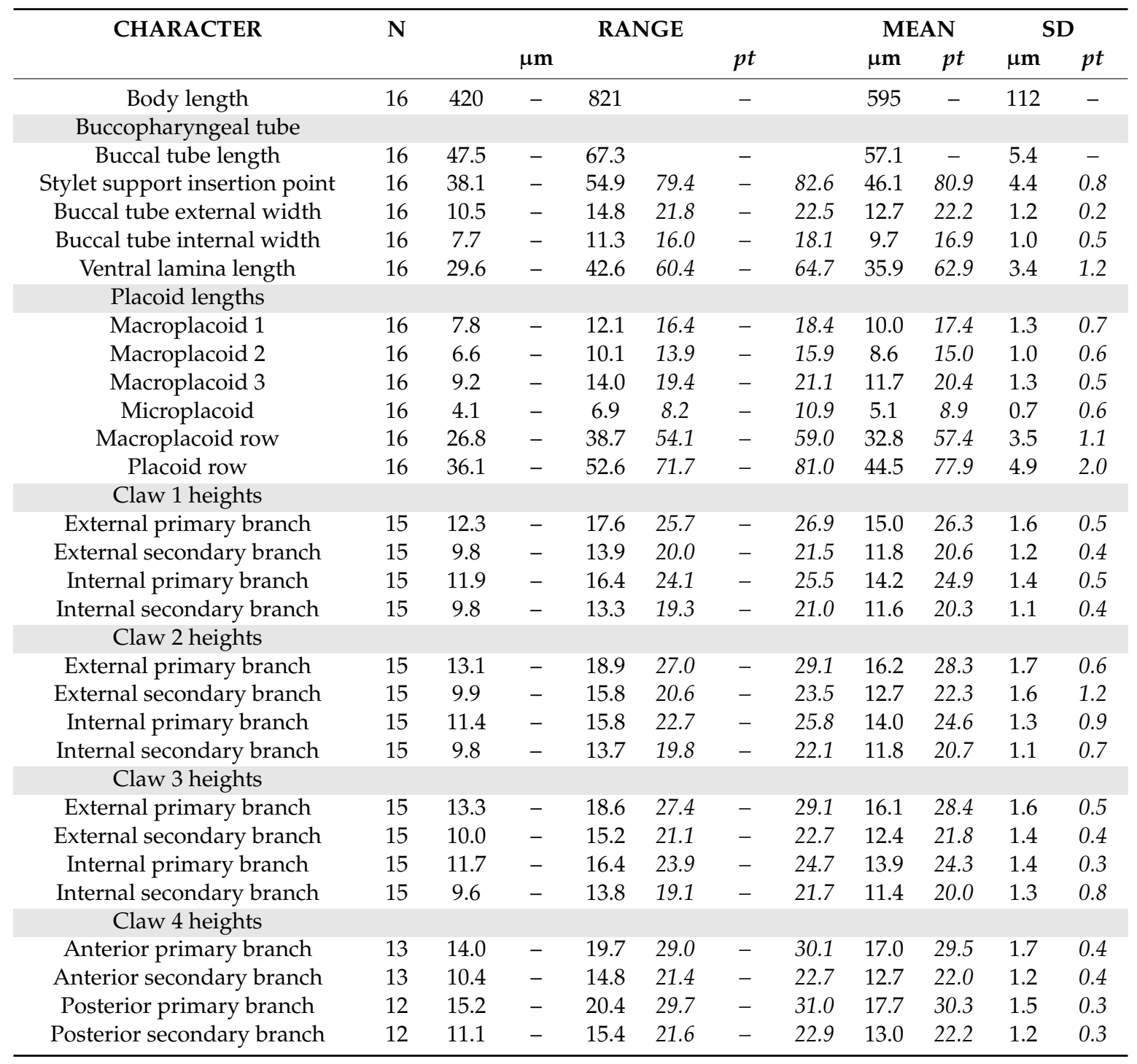


Table 4. Measurements [in $\mu \mathrm{m}$ ] of selected morphological structures of eggs of the Antarctic population of Paramacrobiotus fairbanksi Schill, Förster, Dandekar \& Wolf [25] mounted in Hoyer's medium (N-number of eggs/structures measured, RANGE refers to the smallest and the largest structure among all measured eggs; SD-standard deviation). * except of values of ratio which is presented as percentage and number of processes on the egg circumference which is as number.

\begin{tabular}{ccccccc}
\hline CHARACTER & N & \multicolumn{2}{c}{ RANGE } & MEAN & SD \\
\hline Egg bare diameter & 16 & 68.5 & - & 82.0 & 76.5 & 3.5 \\
Egg full diameter & 16 & 90.2 & - & 107.0 & 99.1 & 3.6 \\
Process height & 48 & 10.1 & - & 14.5 & 12.3 & 0.9 \\
Process base width & 48 & 14.6 & - & 19.8 & 16.8 & 1.4 \\
* Process base/height ratio & 48 & $130 \%$ & - & $146 \%$ & $137 \%$ & $5 \%$ \\
Inter-process distance & 48 & 4.8 & - & 8.1 & 6.1 & 0.7 \\
$*$ Number of processes on the egg circumference & 16 & 12 & - & 12 & 12.0 & 0.0 \\
\hline
\end{tabular}

Table 5. Measurements (in $\mu \mathrm{m}$ ) and $p t$ values of selected morphological structures of individuals of the Polish (cultured) population of Paramacrobiotus fairbanksi Schill, Förster, Dandekar and Wolf [25] mounted in Hoyer's medium (N, number of specimens/structures measured; RANGE refers to the smallest and the largest structure among all measured specimens; SD, standard deviation; $p t$, ratio of the length of a given structure to the length of the buccal tube expressed as a percentage).

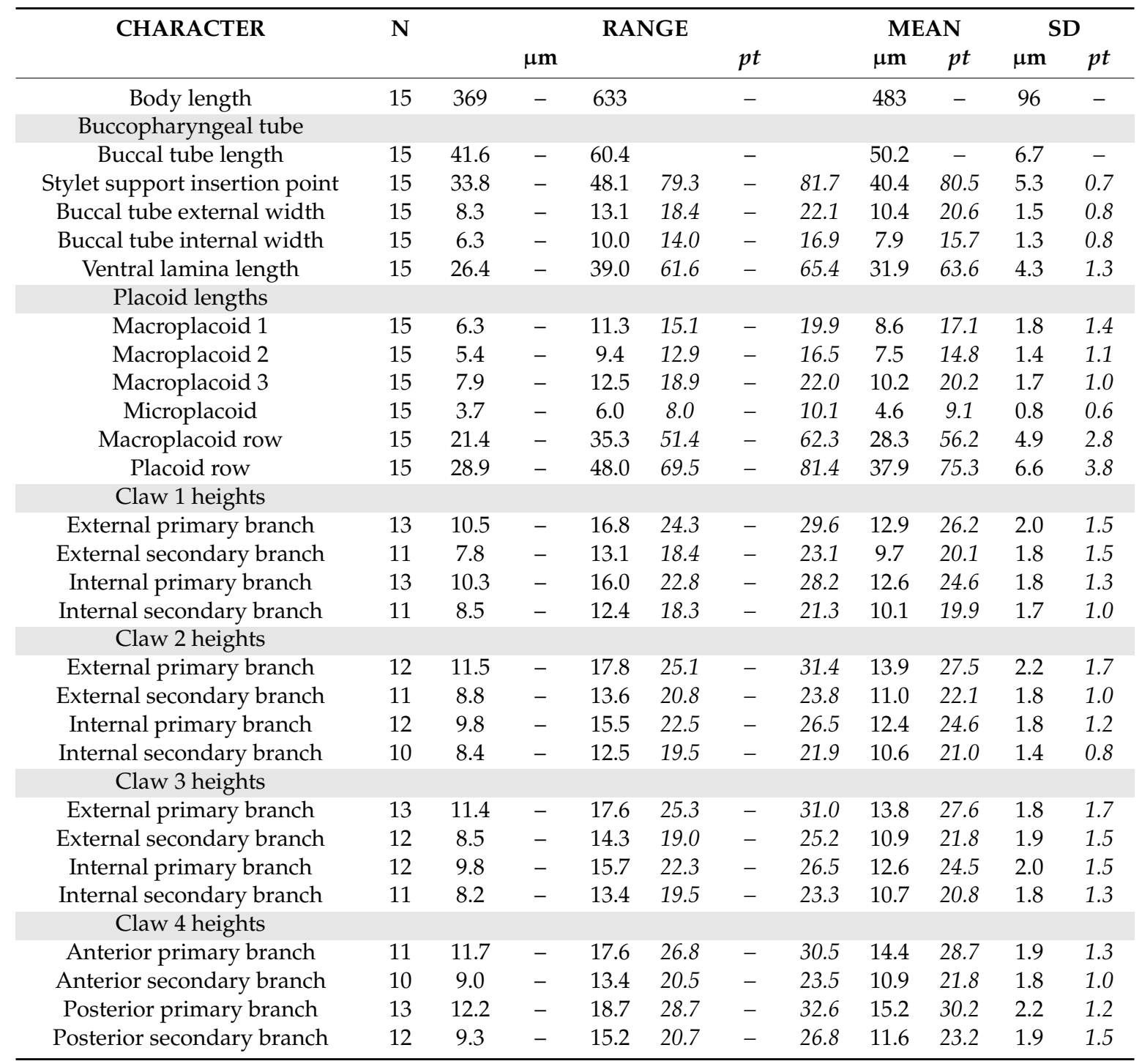


Table 6. Measurements (in $\mu \mathrm{m}$ ) of selected morphological structures of eggs of the Polish (cultured) population of Paramacrobiotus fairbanksi Schill, Förster, Dandekar and Wolf [25] mounted in Hoyer's medium (N, number of eggs/structures measured; RANGE refers to the smallest and the largest structure among all measured eggs; $\mathrm{SD}$, standard deviation). * except of values of ratio which is presented as percentage and number of processes on the egg circumference which is as number.

\begin{tabular}{|c|c|c|c|c|c|c|}
\hline \multirow{2}{*}{$\begin{array}{c}\text { CHARACTER } \\
\text { Egg bare diameter }\end{array}$} & \multirow{2}{*}{$\begin{array}{l}\mathbf{N} \\
15\end{array}$} & \multicolumn{3}{|c|}{ RANGE } & \multirow{2}{*}{$\begin{array}{c}\text { MEAN } \\
66.2\end{array}$} & \multirow{2}{*}{$\begin{array}{l}\text { SD } \\
4.9\end{array}$} \\
\hline & & 59.4 & - & 75.0 & & \\
\hline Egg full diameter & 15 & 84.6 & - & 98.7 & 91.4 & 4.3 \\
\hline Process height & 45 & 11.5 & - & 16.5 & 13.9 & 1.3 \\
\hline Process base width & 45 & 14.3 & - & 19.2 & 16.4 & 1.1 \\
\hline${ }^{*}$ Process base/height ratio & 45 & $100 \%$ & - & $136 \%$ & $118 \%$ & $11 \%$ \\
\hline Inter-process distance & 45 & 3.8 & - & 8.1 & 5.5 & 0.8 \\
\hline${ }^{*}$ Number of processes on the egg circumference & 15 & 11 & - & 12 & 11.5 & 0.5 \\
\hline
\end{tabular}

Table 7. Measurements (in $\mu \mathrm{m}$ ) and $p t$ values of selected morphological structures of individuals of the American (Alaskan) population of Paramacrobiotus fairbanksi Schill, Förster, Dandekar and Wolf [25] mounted in Hoyer's medium ( N, number of specimens/structures measured; RANGE refers to the smallest and the largest structure among all measured specimens; SD, standard deviation, $p t$, ratio of the length of a given structure to the length of the buccal tube expressed as a percentage). * measurement based partially on Schill et al. [25].

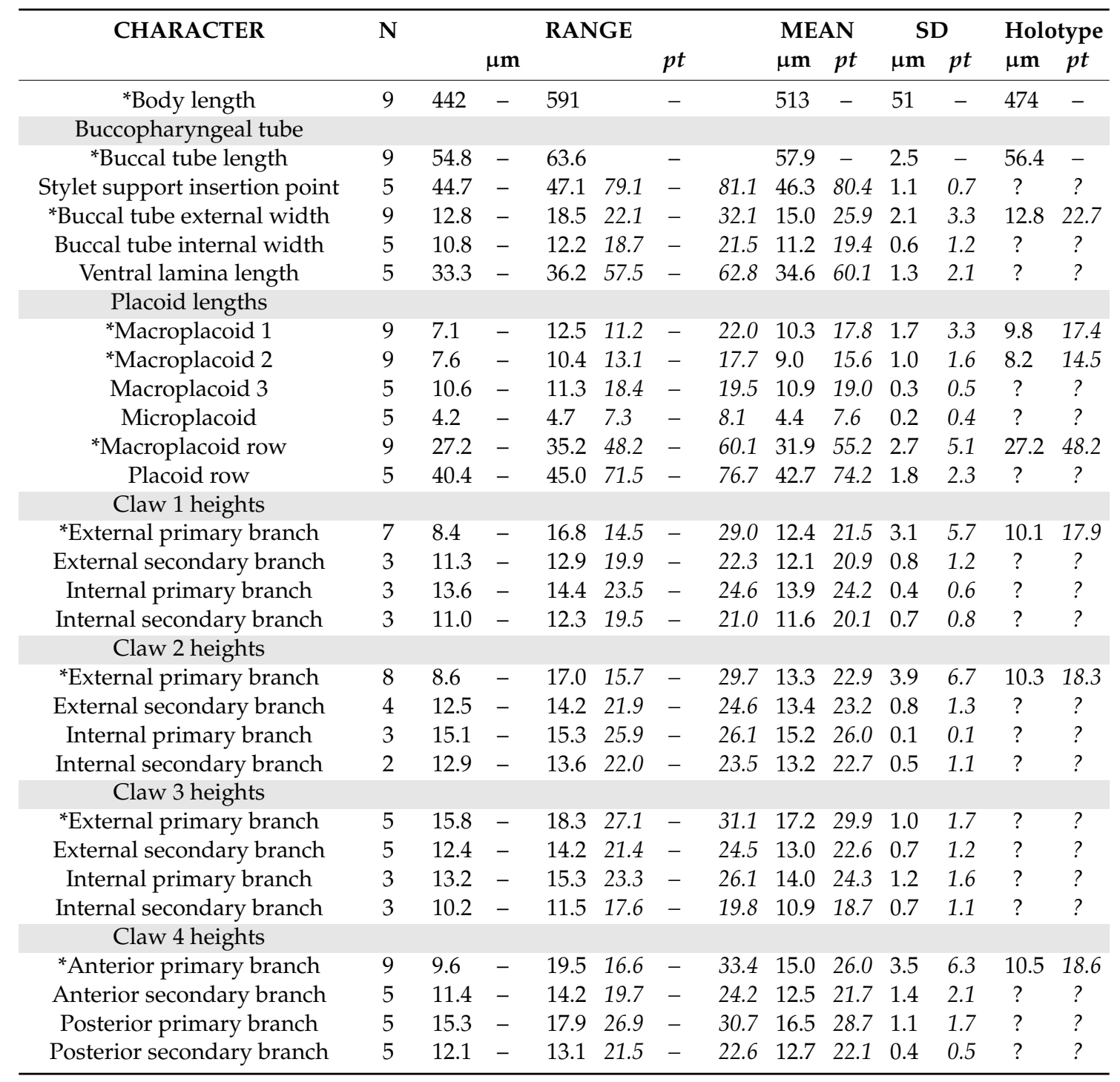


Table 8. Measurements (in $\mu \mathrm{m}$ ) of selected morphological structures of eggs of the American (Alaskan) population of Paramacrobiotus fairbanksi Schill, Förster, Dandekar and Wolf [25] mounted in Hoyer's medium (N, number of eggs/structures measured; RANGE refers to the smallest and the largest structure among all measured eggs; SD, standard deviation). * except of values of ratio which is presented as percentage and number of processes on the egg circumference which is as number; ${ }^{* *}$ measurement based partially on Schill et al. [25].

\begin{tabular}{ccccccc}
\hline CHARACTER & N & \multicolumn{2}{c}{ RANGE } & MEAN & SD \\
\hline$* *$ Egg bare diameter & 18 & 62.1 & - & 82.6 & 70.9 & 5.5 \\
$* *$ Egg full diameter & 18 & 84.1 & - & 105.8 & 92.5 & 6.1 \\
* Process height & 24 & 6.3 & - & 14.3 & 11.3 & 1.8 \\
Process base width & 24 & 14.1 & - & 22.6 & 18.0 & 2.4 \\
$*, * *$ Process base/height ratio & 24 & $120 \%$ & - & $325 \%$ & $164 \%$ & $43 \%$ \\
Inter-process distance & 9 & 3.4 & - & 11.5 & 6.1 & 2.9 \\
$*, * *$ Number of processes on the egg circumference & 18 & 10 & - & 20 & 13.9 & 2.5 \\
\hline
\end{tabular}

Table 9. Measurements (in $\mu \mathrm{m}$ ) and $p t$ values of selected morphological structures of individuals of the Italian population of Paramacrobiotus fairbanksi Schill, Förster, Dandekar and Wolf [25] mounted in Hoyer's medium (N, number of specimens/structures measured; RANGE refers to the smallest and the largest structure among all measured specimens; SD, standard deviation, $p t$, ratio of the length of a given structure to the length of the buccal tube expressed as a percentage).

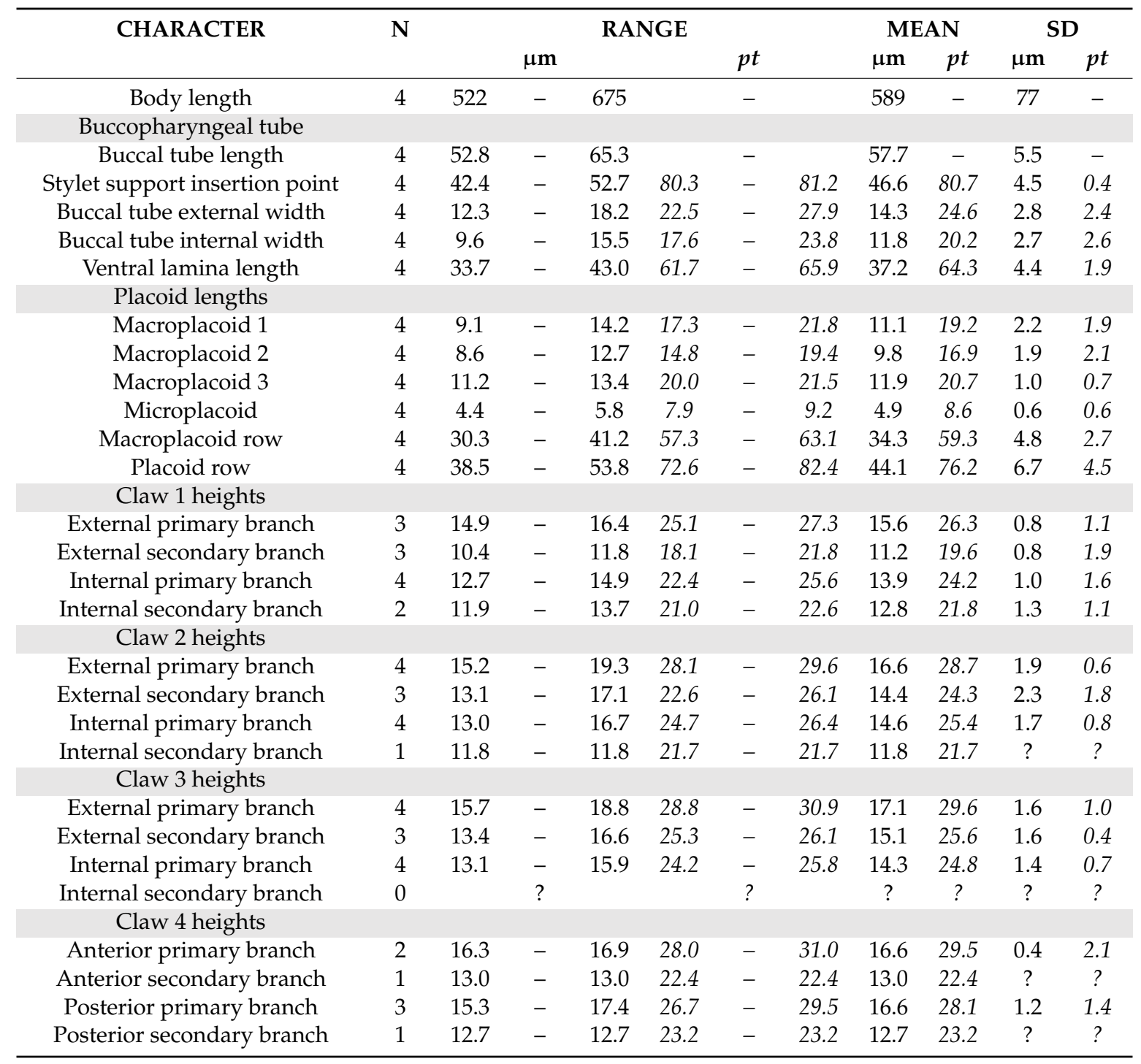


Table 10. Measurements (in $\mu \mathrm{m}$ ) of selected morphological structures of egg of the Italian population of Paramacrobiotus fairbanksi Schill, Förster, Dandekar and Wolf [25] mounted in Hoyer's medium (N, number of eggs/structures measured; RANGE refers to the smallest and the largest structure among all measured eggs; SD, standard deviation). * except of values of ratio which is presented as percentage and number of processes on the egg circumference which is as number.

\begin{tabular}{ccccccc}
\hline CHARACTER & N & & RANGE & & MEAN & SD \\
\hline Egg bare diameter & 1 & 67.0 & - & 67.0 & 67.0 & - \\
Egg full diameter & 1 & 90.2 & - & 90.2 & 90.2 & - \\
Process height & 3 & 11.0 & - & 17.3 & 13.3 & 3.5 \\
Process base width & 3 & 15.8 & - & 20.8 & 18.7 & 2.6 \\
* Process base/height ratio & 3 & $112 \%$ & - & $180 \%$ & $145 \%$ & $34 \%$ \\
Inter-process distance & 3 & 4.0 & - & 5.0 & 4.4 & 0.5 \\
* Number of processes on the egg circumference & 1 & 11 & - & 11 & 11.0 & - \\
\hline
\end{tabular}

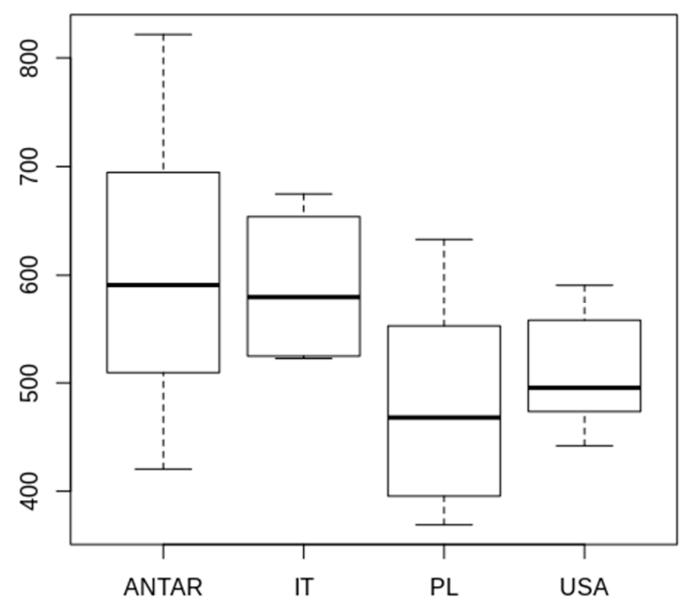

Figure 4. Differences in the body length (in micrometres $(\mu \mathrm{m})$ ) between the studied populations of Paramacrobiotus fairbanksi Schill, Förster, Dandekar and Wolf [25] (Antar, Antarctic; IT, Italy; PL, Poland; USA, USA). Minimum, maximum, median, first quartile, and third quartile for each population are presented.

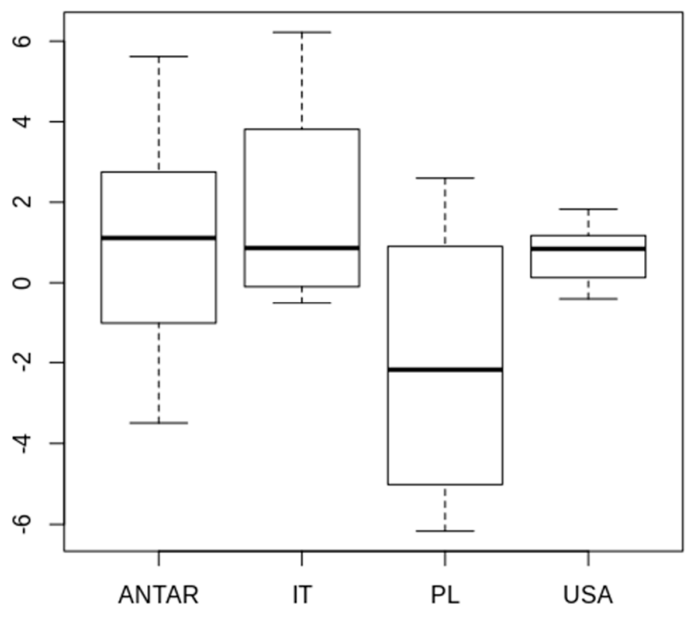

Figure 5. Differences between the studied populations of Paramacrobiotus fairbanksi Schill, Förster, Dandekar and Wolf [25] expressed by the first component of PCA performed on the measurements of chosen morphological structures (Antar, Antarctic; IT, Italy; PL, Poland; USA, USA). Minimum, maximum, median, first quartile, and third quartile for each population are presented. 


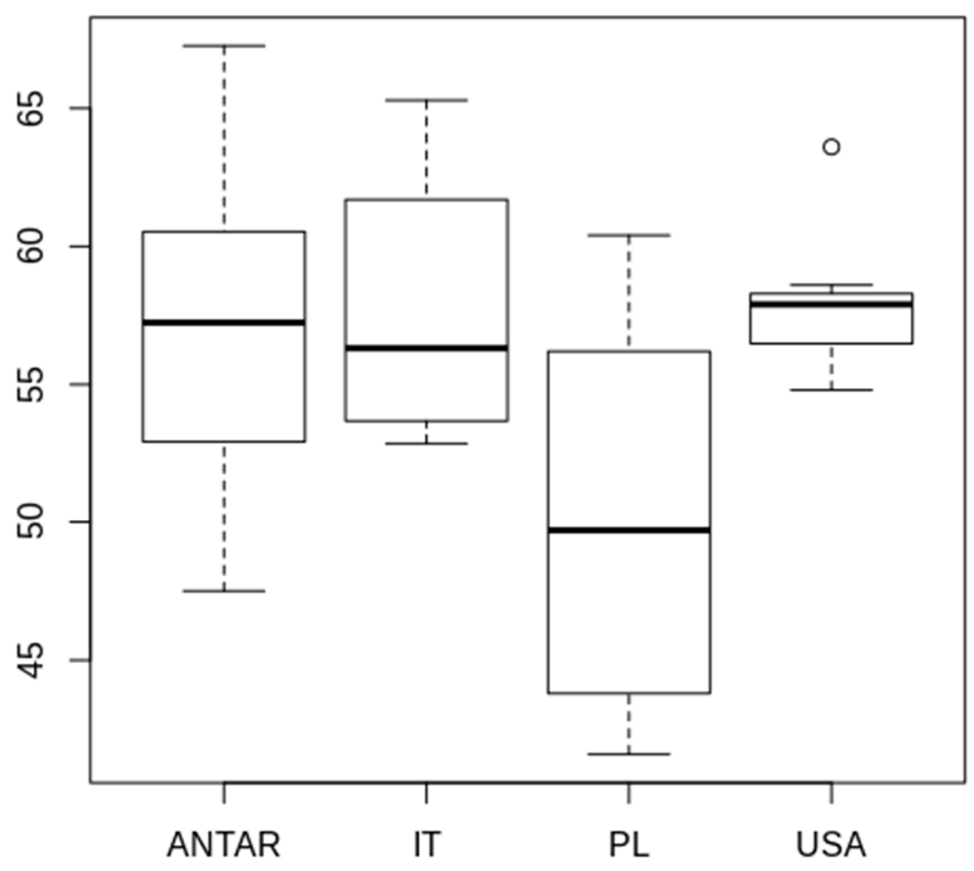

Figure 6. Differences in the buccal tube length (in micrometres $(\mu \mathrm{m})$ ) between the studied populations of Paramacrobiotus fairbanksi Schill, Förster, Dandekar and Wolf [25] (Antar, Antarctic; IT, Italy; PL, Poland; USA, USA). Minimum, maximum, median, first quartile, and third quartile for each population are presented.

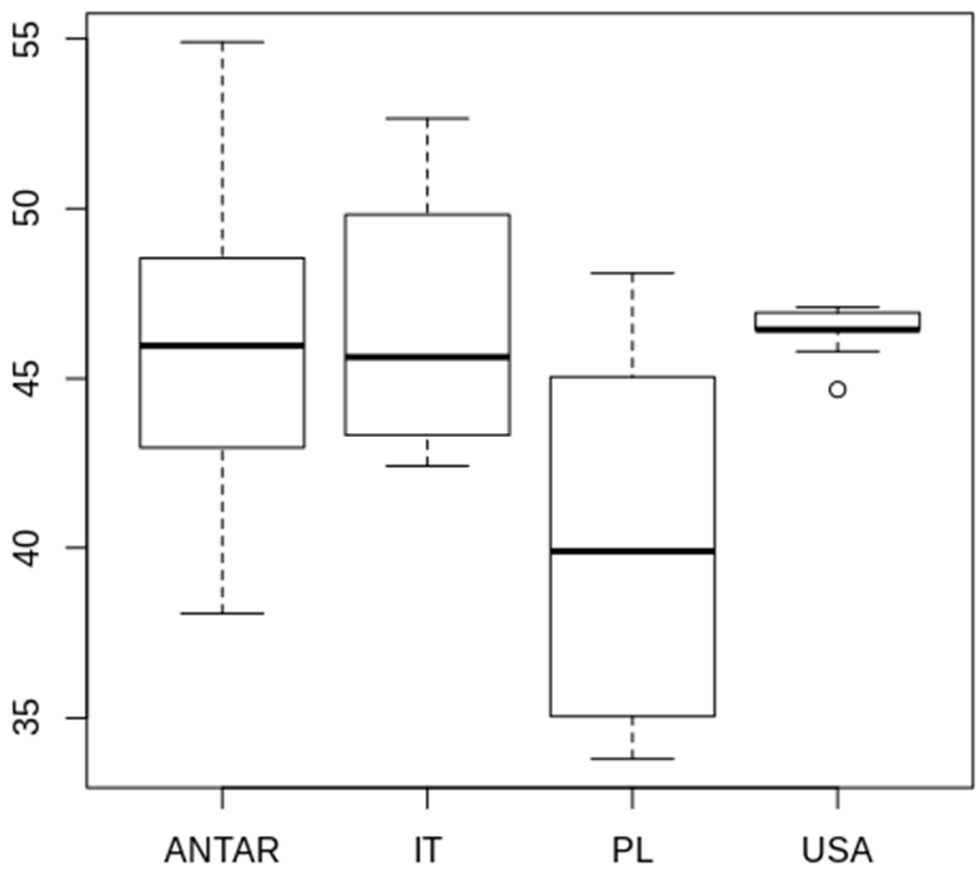

Figure 7. Differences in the stylet supports insertion points (in micrometres $(\mu \mathrm{m})$ ) between the studied populations of Paramacrobiotus fairbanksi Schill, Förster, Dandekar and Wolf [25] (Antar, Antarctic; IT, Italy; PL, Poland; USA, USA). Minimum, maximum, median, first quartile, and third quartile for each population are presented. 


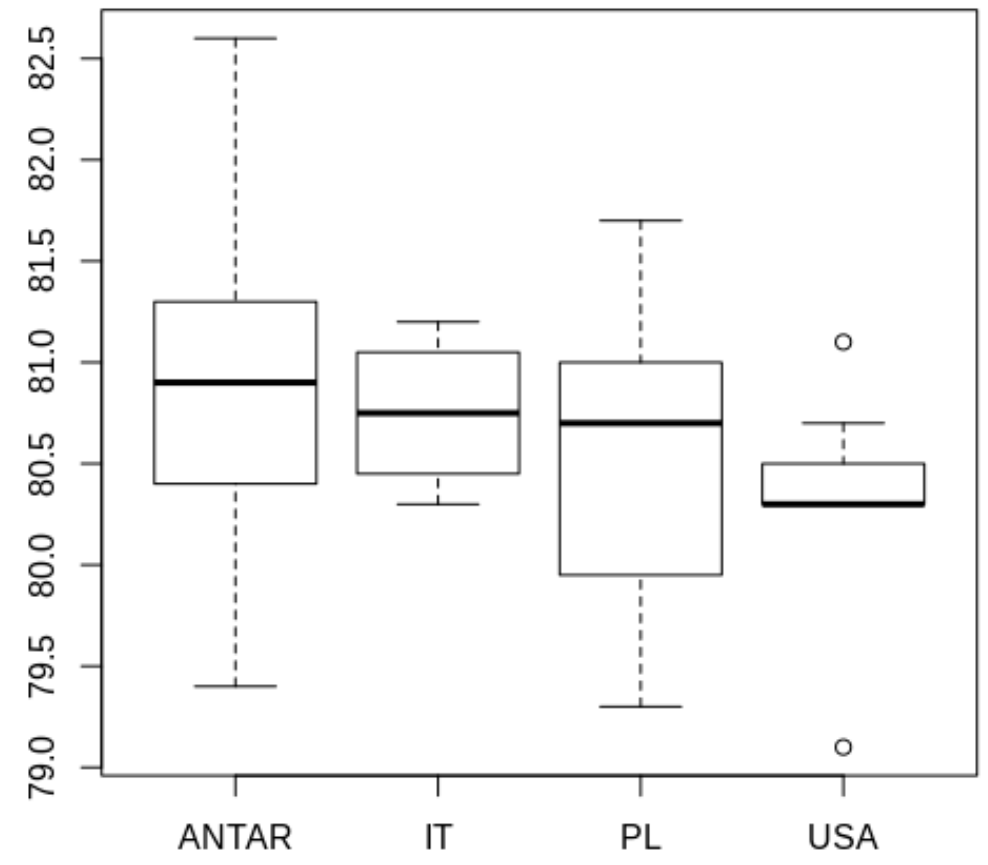

Figure 8. Differences in the $p t$ of stylet supports insertion points ratio between the studied populations of Paramacrobiotus fairbanksi Schill, Förster, Dandekar and Wolf [25] (Antar, Antarctic; IT, Italy; PL, Poland; USA, USA). Minimum, maximum, median, first quartile, and third quartile for each population are presented.

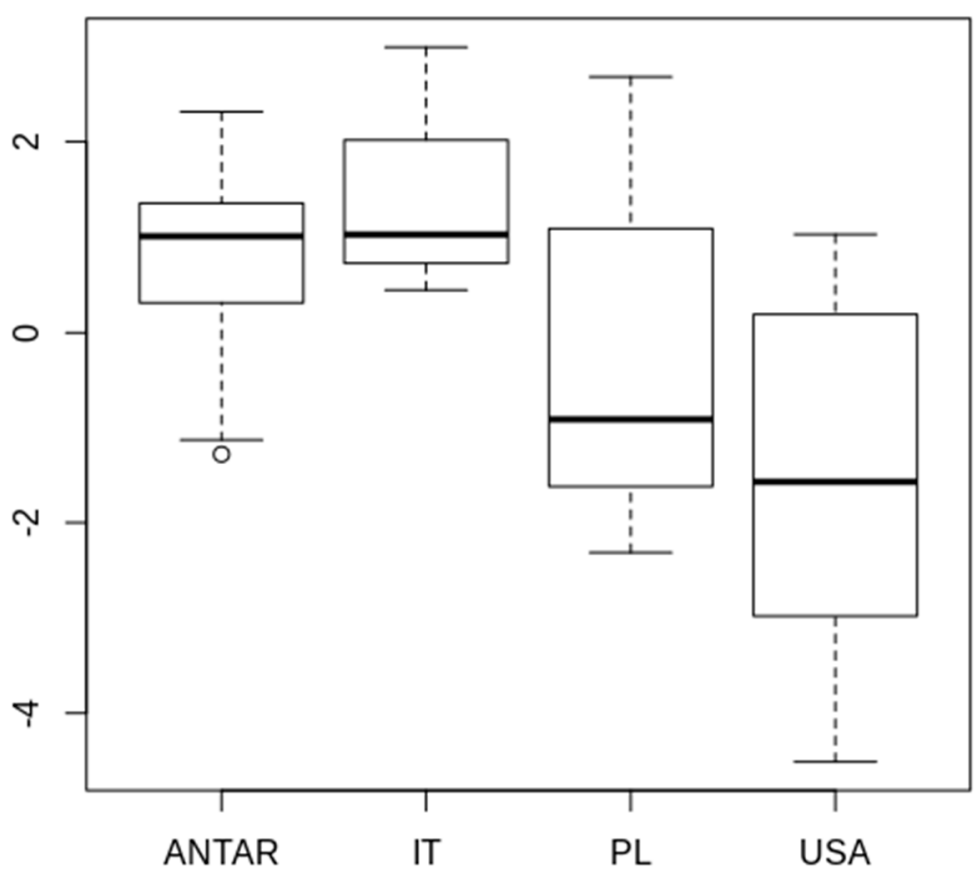

Figure 9. Differences between the studied populations of Paramacrobiotus fairbanksi Schill, Förster, Dandekar and Wolf [25] expressed by the first component of PCA performed on $p t$ ratios of lengths of the measurements of chosen morphological structures (Antar, Antarctic; IT, Italy; PL, Poland; USA, USA). Minimum, maximum, median, first quartile, and third quartile for each population are presented. 


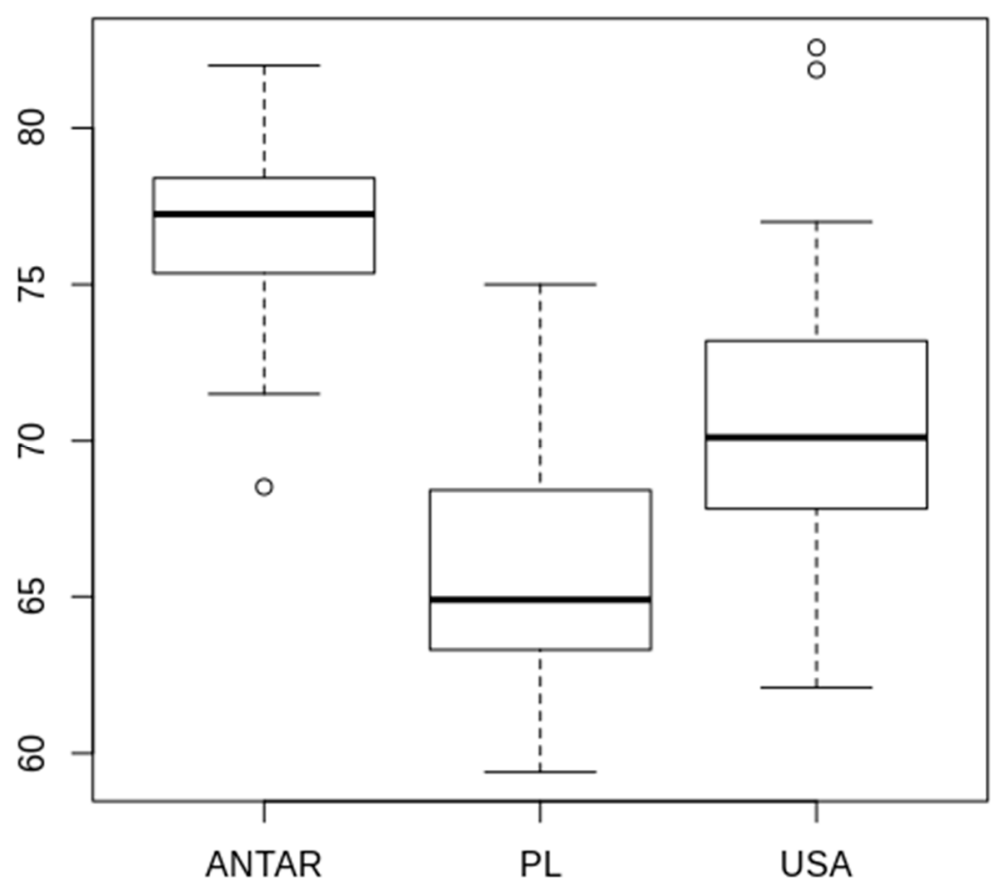

Figure 10. Differences in the egg bare diameter between the studied populations of Paramacrobiotus fairbanksi Schill, Förster, Dandekar and Wolf [25] (Antar, Antarctic; PL, Poland; USA, USA). Minimum, maximum, median, first quartile, and third quartile for each population are presented.

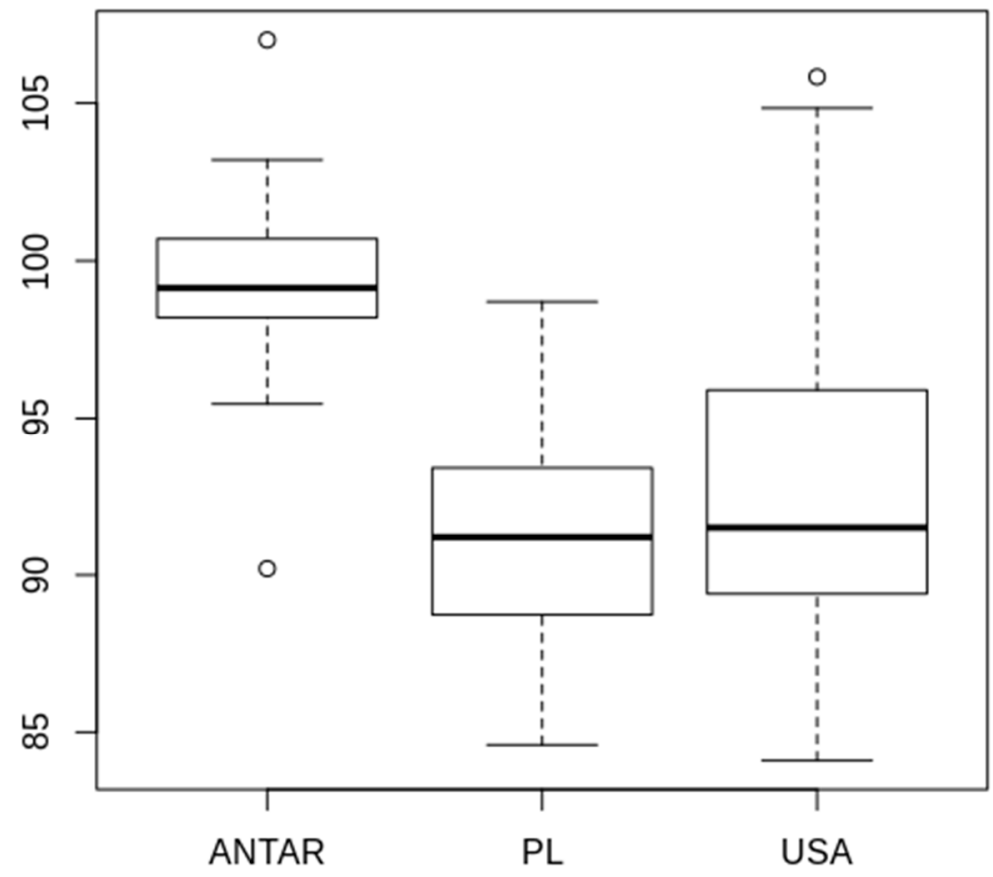

Figure 11. Differences in the egg full diameter between the studied populations of Paramacrobiotus fairbanksi Schill, Förster, Dandekar and Wolf [25] (Antar, Antarctic; PL, Poland; USA, USA). Minimum, maximum, median, first quartile, and third quartile for each population are presented. 


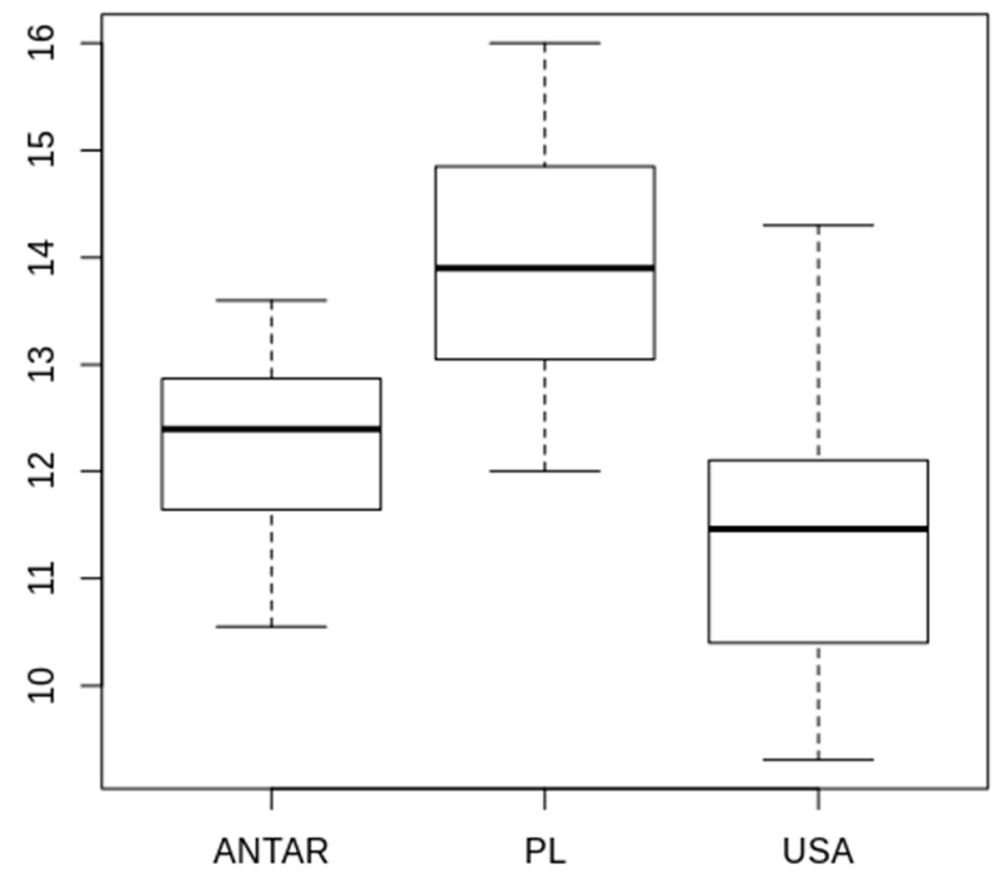

Figure 12. Differences in the egg processes height between the studied populations of Paramacrobiotus fairbanksi Schill, Förster, Dandekar and Wolf [25] (Antar, Antarctic; PL, Poland; USA, USA). Minimum, maximum, median, first quartile, and third quartile for each population are presented.

The ANOVA performed on EBD measurements of eggs ( $\mathrm{df}=2, \mathrm{~F}=18.72, p<0.0001, \mathrm{n}=49$ ) showed significant differences between all the populations, where the eggs in Polish population were significantly smaller than these from Alaska $(p=0.0197)$ and Antarctica $(p<0.0001)$ and the eggs from Alaskan population clearly smaller than those from Antarctic $(p=0.0033)$ (Figure 10). Analysis on EFD values, however, showed no differences between measurements of Polish and Alaskan eggs $(p=1$, $\mathrm{n}=49$, Figure 11), but eggs in Antarctic population were significantly bigger than these collected in Alaska $(p=0.0008)$ and Poland $(p=0.0002)$, the model was significant at $\mathrm{p}<0.0001(\mathrm{df}=2, \mathrm{~F}=11.72)$. The differences between the studied populations were also visible in the size of $\mathrm{PH}(\mathrm{df}=2, \mathrm{~F}=18.91$, $p<0.0001, \mathrm{n}=44)$. Egg processes were longest in Polish population in comparison to both Antarctic $(p=0.0009)$ and Alaskan $(p<0.0001)$ populations. There was no significant difference between the length of egg processes in Alaskan and Antarctic populations $(p=0.1252, \mathrm{n}=49$, Figure 12).

\subsection{Genetic Comparison of Different Populations of the Pam. fairbanksi}

All DNA barcode sequences of Pam. fairbanksi from Antarctic were obtained from DNA extracted from the eggs. In DNA extracted from adult individuals, signs of degradation were observed; however, newly designed degenerate primers to amplify COI marker allowed confirmation of molecular species identification. The COI sequences (GenBank accession numbers: MN964281-MN964282) were $639 \mathrm{bp}$ long (using HCO2198 and LCO1490 primers and 392 bp long using designed ParCOIF and ParCOIR primers) and represented only one haplotype. No insertions, deletions, or stop codons were identified. The translation was successfully carried out with the invertebrate mitochondrial codon table and the -2 th reading frame. The p-distances between COI haplotypes of all sequenced Pam. fairbanksi populations from Antarctica, Italy, Spain, USA (Alaska), and Poland ranged from $0.002 \%$ to $0.005 \%$ (an average distance of $0.003 \%$ ). In case of COI polymorphism analyses, only one haplotype was observed in populations from Antarctica, USA (Alaska), and Poland, two haplotypes were found in population from Spain, and six haplotypes were observed in population from Italy (for details see Table 11). 
Table 11. Estimates of evolutionary divergence between COI haplotypes (H1-H10 *) based on p-distances (below the diagonal). Standard error estimates are shown above the diagonal and were obtained by a bootstrap procedure (500 replicates).

\begin{tabular}{|c|c|c|c|c|c|c|c|c|c|c|}
\hline & H1 & H2 & H3 & H4 & H5 & H6 & H7 & H8 & H9 & H10 \\
\hline H1 & & 0.003 & 0.002 & 0.002 & 0.002 & 0.002 & 0.002 & 0.002 & 0.002 & 0.002 \\
\hline H2 & 0.005 & & 0.003 & 0.002 & 0.003 & 0.003 & 0.003 & 0.003 & 0.003 & 0.003 \\
\hline H3 & 0.003 & 0.005 & & 0.002 & 0.002 & 0.002 & 0.002 & 0.002 & 0.002 & 0.002 \\
\hline H4 & 0.002 & 0.003 & 0.002 & & 0.002 & 0.002 & 0.002 & 0.002 & 0.002 & 0.002 \\
\hline H5 & 0.003 & 0.005 & 0.003 & 0.002 & & 0.002 & 0.002 & 0.002 & 0.002 & 0.002 \\
\hline H6 & 0.002 & 0.005 & 0.003 & 0.002 & 0.003 & & 0.002 & 0.002 & 0.002 & 0.002 \\
\hline H7 & 0.003 & 0.005 & 0.003 & 0.002 & 0.003 & 0.003 & & 0.002 & 0.002 & 0.002 \\
\hline H8 & 0.003 & 0.005 & 0.003 & 0.002 & 0.003 & 0.003 & 0.003 & & 0.002 & 0.002 \\
\hline H9 & 0.003 & 0.005 & 0.003 & 0.002 & 0.003 & 0.003 & 0.003 & 0.003 & & 0.002 \\
\hline H10 & 0.003 & 0.005 & 0.003 & 0.002 & 0.003 & 0.003 & 0.003 & 0.003 & 0.003 & \\
\hline
\end{tabular}

* The list of COI haplotypes: H1, Antarctica (GenBank accession numbers: MN964281-MN964282, our study), Poland (GenBank accession number: KU513421, [27]); H2, Spain (GenBank accession number: FJ435809, [26]; H3, Italy (GenBank accession number: AY598778, [29]; H4, Italy (GenBank accession numbers: AY598779, MK041003, MK041007, MK041009, MK041011, [28,29]; H5, USA (Alaska) (GenBank accession number: EU244597, [25]; H6, Spain (GenBank accession number: FJ435808, [26]; H7, Italy (GenBank accession number: MK041004, [28]; H8, Italy (GenBank accession number: MK041005, [28]; H9, Italy (GenBank accession numbers: MK041006, MK041008, [28]; H10, Italy (GenBank accession number: MK041010, [28].

The 18S rRNA sequences (GenBank accession numbers: MN960302-MN960304) were 1717 to 1725 bp long and one nucleotide substitution was found. Comparing with available in GenBank sequences of Pam. fairbanksi (from Italy and Alaska, alignment sequences were trimmed to $822 \mathrm{bp}$, see [28]) also showed one nucleotide substitution.

The 28S rRNA sequences (GenBank accession numbers: MN960306-MN960307) were 796 to $800 \mathrm{bp}$ long and one nucleotide substitution was found. We obtained $28 \mathrm{~S}$ rRNA sequences for Pam. fairbanksi for the very first time, so that no sequences of this species were available for comparison.

\section{Discussion}

\subsection{Taxa}

Most of species found in the present study are endemic to the Antarctic region. Barbaria pseudowendti, Das. improvisus, and Mes. blocki are known only from Enderby Land, East Antarctica [12]. Acutuncus antarcticus is a pan-Antarctic species, however, as it is a parthenogenetic species some populations are isolated and show quite large genetic distance which can suggest a process of speciation [5].

Hebesuncus mollispinus has quite recently been described as a species from Charcot Island, close to Antarctic Peninsula (West Antarctica) [15]. It was also reported from Alamode and Terra Firma Islands (close to Antarctic Peninsula), South Georgia (sub-Antarctica), and Argentinian Andes [15,66]. The present report is the first in East Antarctica. Such geographical range of this species suggests their wide distribution in the Antarctic region and also inhabiting glacier regions in South America.

The taxonomic status of Mil. quadrifidum is unclear, especially that their original description is very scanty [51] and lacks a detailed description of animal morphology. In the past it was synonymized with nominal Mil. tar. tardigradum Doyère [41], but recently Morek et al. [67] proposed it as a valid species being the only member of the genus Milnesium with four points on all secondary branches of claws. However, the same authors also suggested that this species needs a detailed redescription. Only recently, Kaczmarek et al. [68] described another species with four points on secondary branches of claws IV, i.e., Mil. wrightae Kaczmarek, Grobys, Kulpa, Bartylak, Kmita, Kepel, Kepel and Roszkowska [68]. Dastych [52] reported Mil. tar. tardigradum from King George Island and Enderby Land with many claw aberrations (i.e., different number of points on secondary branches of claws, even in the same animal). As the number of points on claws is rather constant (but may change during ontogenesis) and 
species-specific character $[67,69,70]$, it should be considered that specimens of Mil. tar. tardigradum reported by Dastych [52] could possibly belong to a different species. In this situation it is impossible to determine a detailed morphology of Mil. quadrifidum or their distribution. The specimens found in the present study correspond to the original description of Mil. quadrifidum, but taking into consideration all the taxonomic problems addressed for this species, their presence in Antarctica should be confirmed after detailed redescription of this species from the type locality.

Paramacrobiotus fairbanksi was described from Alaska (USA) and later reported from Italy, Poland and Spain [25-28], and now we have provided the next record from Antarctica. This species perfectly fits the model taxon for the "everything is everywhere" hypothesis, i.e., is microscopic, easy to disperse, is able to cryptobiosis and it is parthenogenetic. However, before the final conclusion that Pam. fairbanksi is a true cosmopolitan species, its presence should also be confirmed on other continents.

Due to the lack of eggs, determination of the specimens of the genus Mesobiotus from two samples was not possible. It is of course highly probable that these specimens belong to Mes. blocki which was also found in the present study.

\subsection{Morphometric Comparison of Different Populations of the Pam. fairbanksi}

It is clearly visible in Tables 3-10 and Figures 1-9 and supported by the statistical analyses that some small morphometric differences are present between the populations of Pam. fairbanksi from different regions. However, measurements of all structures generally overlap which rather clearly allows the identification of this species even without genetic markers. This suggests that, based on the morphology, all specimens, even collected in different regions, should be correctly classified if a proper number of specimens is examined. Nonetheless, specimens from the Polish population are the smallest and lay the smallest eggs, equipped, however, with the longest egg processes. All observations and measurements of the Polish and Alaskan population of Pam. fairbanksi are based on cultured specimens, whereas in other cases specimens were extracted from the wild. In general, in both cultured populations, the length of the body is the smallest which could be caused by the well-known phenomenon when cultured populations of various animal species are dwarfing as a result of suboptimal conditions, high culture densities, and inbreeding. In addition, the measurements of other morphological structures of adults in Polish population are also the smallest, whereas, in contrast, in Alaska they are similar to those from Antarctic and Italy. Therefore, the observed dissimilarities could well be a sign of conserved differences in the morphology of the populations as a result of ongoing speciation.

It is also visible that the eggs of the Antarctic population are clearly bigger and have rather small egg processes. At present, we suggest that the harsh conditions in Antarctica favor laying larger eggs, while in cultures the eggs are smaller because of the lack of such selective pressure. In contrast, it is quite strange that the number of processes on the egg circumference in the Alaskan population is higher (10 to 20 processes, based on data from the original description) than in other populations (11 to 12 processes, based on the own observations). However, this could be an artefact caused by differences in the methodology used. Summarizing, at present we should consider this species as effectively morphologically defined with small interpopulation differences.

\subsection{Genetic Comparison of Different Populations of the Pam. fairbanksi}

Paramacrobiotus fairbanksi has a wide distribution and until now was observed in Italia, Spain [26], Poland [27], and Alaska [25]. From each locality, COI sequences of Pams fairbanksi are available. In the case of nucleotide markers, the $18 \mathrm{~S}$ rRNA sequences have been obtained from Italia, Alaska, and presented in our study from Antarctica. In turn, the 28S rRNA sequences have been obtained only from our population from Antarctica. As examined in this study, Pam. fairbanksi population from Antarctica is the most similar to the population from Poland, with the same COI haplotype (Figure 13). Molecular analysis based on $18 \mathrm{~S}$ rRNA sequences indicated no differences between our population from Antarctica and populations from Italy, whereas those based on COI sequences revealed low genetic 
distances, i.e., 0.002 to 0.003 . The genetic distances, based on COI markers among Pam. fairbanksi from Antarctica and Alaska was 0.003, and one nucleotide substitution was indicated in 18S rRNA sequences. On the basis of this molecular data for populations from very distant regions, with physical barriers to gene flow, we showed the low evolutionary rate of Pam. fairbanksi.

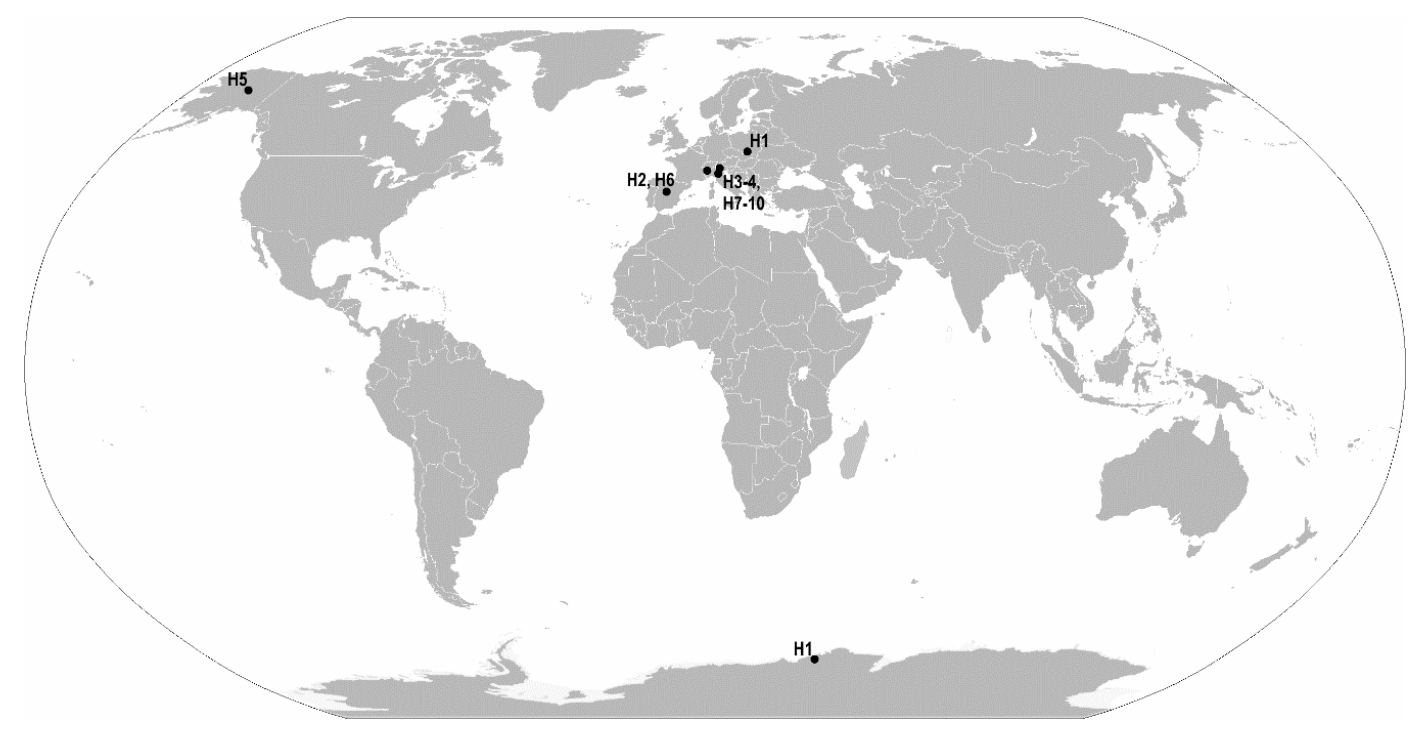

Figure 13. A World map with indicated haplotypes of Paramacrobiotus fairbanksi Schill, Förster, Dandekar and Wolf [25] found in different localities.

Author Contributions: Conceptualization, Ł.K., M.M., B.G., M.R.; Methodology, Ł.K., M.M., B.G.; Software, Ł.K., M.M., B.G.; Validation, Ł.K., M.M., U.K., K.K., I.P., B.G., M.R.; Formal analysis, Ł.K.; Investigation, Ł.K., M.M., U.K., K.K., I.P., B.G., M.R.; Resources: Ł.K., M.M., I.P.; Data curation, Ł.K.; Writing—original draft preparation, Ł.K., M.M., B.G., M.R.; Writing—review and editing, Ł.K., M.M., U.K., K.K., I.P., B.G., M.R.; Visualization: B.G. M.R. Supervision, Ł.K.; Project administration, Ł.K.; Funding acquisition, Ł.K.; All authors have read and agreed to the published version of the manuscript.

Funding: The study was supported by the research grant of the National Science Centre, Poland, NCN 2016/21/B/NZ4/00131.

Acknowledgments: The isogenic strain of Pam. fairbanksi (Pam.fai_I_PL.018) was kindly provided by the Michalczyk Lab (Jagiellonian University, Kraków, Poland). The strain was established from a female isolated from a moss sample collected by Piotr Gasiorek and has been maintained by Daniel Stec. We are also grateful to Robert Sobkowiak (Adam Mickiewicz University, Poznań, Poland) and Edyta Fiałkowska (Jagiellonian University, Kraków, Poland) for providing nematodes and rotifers as a food for the tardigrades.

Conflicts of Interest: The authors declare no conflict of interest.

\section{References}

1. Kimble, J.M. Cryosols. Permafrost-Affected Soils; Springer: Berlin/Heidelberg, Germany, 2004; pp. 1-94.

2. Velasco-Castrillón, A.; Gibson, J.A.E.; Stevens, M.I. A review of current Antarctic limno-terrestrial microfauna. Polar Biol. 2014, 37, 1517-1531.

3. Richters, F. Vorläufiger Bericht über die antarktische Moosfauna. Verh. Dtsch. Zool. Ges. 1904, 14, $236-239$.

4. Pugh, P.J.A.; Convey, P. Surviving out in the cold: Antarctic endemic invertebrates and their refugia. J. Biogeogr. 2008, 35, 2176-2186. [CrossRef]

5. Cesari, M.; McInnes, S.; Bertolani, R.; Rebecchi, L.; Guidetti, R. Genetic diversity and biogeography of the south polar water bear Acutuncus antarcticus (Eutardigrada: Hypsibiidae)—Evidence that it is a truly pan-Antarctic species. Invertebr. Syst. 2016, 30, 635-649. [CrossRef]

6. Guidetti, R.; Bertolani, R. Tardigrade taxonomy: An updated check list of the taxa and a list of characters for their identification. Zootaxa 2005, 845, 1-46. [CrossRef]

7. Degma, P.; Guidetti, R. Notes to the current checklist of Tardigrada. Zootaxa 2007, 1579, 41-53. [CrossRef] 
8. Vicente, F.; Bertolani, R. Considerations on the taxonomy of the Phylum Tardigrada. Zootaxa 2013, 3626, 245-248. [CrossRef]

9. Degma, P.; Bertolani, R.; Guidetti, R. Actual Checklist of Tardigrada Species; Version 35: Edition: 31-07-2019; Università di Modena e Reggio Emilia: Modena, Italy, 2019. [CrossRef]

10. Ramazzotti, G.; Maucci, W. Il Phylum Tardigrada. III edizione riveduta e aggiornata. Mem. Ist. Ital. Idrobiol. 1983, 41, 1-1012.

11. Nelson, D.R.; Guidetti, R.; Rebecchi, L. Phylum Tardigrada. In Ecology and General Biology. Vol. 1. Thorp and Covich's Freshwater Invertebrates; Throp, J.H., Rogers, D.C., Eds.; Academic Press: Cambridge, MA, USA, 2015; pp. 347-380. [CrossRef]

12. Convey, P.; McInnes, S.J. Exceptional tardigrade-dominated ecosystems in Ellsworth Land, Antarctica. Ecology 2005, 86, 519-527. [CrossRef]

13. Binda, M.G.; Pilato, G.; Lisi, O. Remarks on Macrobiotus furciger Murray, 1906 and description of three new species of the furciger group (Eutardigrada, Macrobiotidae). Zootaxa 2005, 1075, 55-68. [CrossRef]

14. McInnes, S.J. Echiniscus corrugicaudatus (Heterotardigrada; Echiniscidae) a new species from Ellsworth Land, Antarctica. Polar Biol. 2010, 33, 59-70. [CrossRef]

15. Pilato, G.; McInnes, S.J.; Lisi, O. Hebesuncus mollispinus (Eutardigrada, Hypsibiidae), a new species from maritime Antarctica. Zootaxa 2012, 3446, 60-68. [CrossRef]

16. Guidetti, R.; Rebecchi, L.; Cesari, M.; McInnes, S.J. Mopsechiniscus franciscae, a new species of a rare genus of Tardigrada from continental Antarctica. Polar Biol. 2014, 37, 1221-1233. [CrossRef]

17. Kaczmarek, Ł.; Janko, K.; Smykla, J.; Michalczyk, Ł. Soil tardigrades from the Antarctic Peninsula with a description of a new species and some remarks on the genus Ramajendas (Eutardigrada, Isohypsibiidae). Polar Rec. 2014, 50, 176-182. [CrossRef]

18. Tsujimoto, M.; McInnes, S.J.; Convey, P.; Imura, S. Preliminary description of tardigrade species diversity and distribution pattern around coastal Syowa Station and inland Sør Rondane Mountains, Dronning Maud Land, East Antarctica. Polar Biol. 2014, 37, 1361-1367. [CrossRef]

19. Vecchi, M.; Cesari, M.; Bertolani, R.; Jönsson, K.I.; Rebecchi, L.; Guidetti, R. Integrative systematic studies on tardigrades from Antarctica identify new genera and new species within Macrobiotoidea and Echiniscoidea. Invertebr. Syst. 2016, 30, 303-322. [CrossRef]

20. Guidetti, R.; McInnes, S.J.; Cesari, M.; Rebecchi, L.; Rota-Stabelli, O. Evolutionary scenarios for the origin of an Antarctic tardigrade species based on molecular clock analyses and biogeographic data. Contrib. Zool. 2017, 86, 97-110. [CrossRef]

21. Pilato, G.; Sabella, G.; D'Urso, V.; Lisi, O. Two new species of Eutardigrada from Victoria Land, Antarctica. Zootaxa 2017, 4317, 541-558. [CrossRef]

22. Dastych, H. Redescription and revalidation of the sub-Antarctic tardigrade Hypsibius murrayi (Richters, 1907) based on the rediscovered type material (Tardigrada, Panarthropoda). Entomol. Heute 2018, 30, 95-115.

23. Kaczmarek, Ł.; Parnikoza, I.; Gawlak, M.; Esefeld, J.; Peter, H.-U.; Kozeretska, I.; Roszkowska, M. Tardigrades from Larus dominicanus Lichtenstein, 1823 nests on the Argentine Islands (maritime Antarctic). Polar Biol. 2018, 41, 283-301. [CrossRef]

24. Guidetti, R.; Massa, E.; Bertolani, R.; Rebecchi, L.; Cesari, M. Increasing knowledge of Antarctic biodiversity: New endemic taxa of tardigrades (Eutardigrada; Ramazzottiidae) and their evolutionary relationships. Syst. Biodivers. 2019, 17, 573-593. [CrossRef]

25. Schill, R.O.; Forster, F.; Dandekar, T.; Wolf, N. Using compensatory base change analysis of internal transcribed spacer 2 secondary structures to identify three new species in Paramacrobiotus (Tardigrada). Org. Divers. Evol. 2010, 10, 287-296. [CrossRef]

26. Guil, N.; Giribet, G. A comprehensive molecular phylogeny of tardigrades-Adding genes and taxa to a poorly resolved phylum-level phylogeny. Cladistics 2012, 28, 21-49. [CrossRef]

27. Kosztyła, P.; Stec, D.; Morek, W.; Gąsiorek, P.; Zawierucha, Z.; Michno, K.; Małek, D.; Hlebowicz, K.; Ufir, K.; Laska, A.; et al. Experimental taxonomy confirms the environmental stability of morphometric traits in a taxonomically challenging group of microinvertebrates. Zool. J. Linn. Soc. 2016, 178, 765-775.

28. Guidetti, R.; Cesari, M.; Bertolani, R.; Altiero, T.; Rebecchi, L. High diversity in species, reproductive modes and distribution within the Paramacrobiotus richtersi complex (Eutardigrada, Macrobiotidae). Zool. Lett. 2019, 5, 1. [CrossRef] 
29. Guidetti, R.; Gandolfi, A.; Rossi, V.; Bertolani, R. Phylogenetic analysis in Macrobiotidae (Eutardigrada, Parachela): A combined morphological and molecular approach. Zool. Scr. 2005, 34, 235-244. [CrossRef]

30. Murray, J. Arctiscoida. Proc. Roy. Irish Acad. 1911, 31, 1-16.

31. Beijerinck, M.W. De infusies en de ontdekking der bakterien. Jaarb. Kon Akad. Wetensch. 1913, 1-28.

32. Baas Becking, L.G.M. Geobiologie of Inleiding Tot de Milieukunde; W.P. Van Stockum \& Zoon N.V: Den Haag, The Netherlands, 1934; pp. 1-263.

33. Cardillo, M.; Bromhan, L. Body size and risk of extinction in Australian mammals. Conserv. Biol. 2001, 15, 1435-1440. [CrossRef]

34. Finlay, B.J. Global dispersal of free living microbial eukaryote species. Science 2002, 296, 1061-1063. [CrossRef]

35. Foissner, W. Biogeography and dispersal of micro-organisms: A review emphasizing protists. Acta Protozool. 2006, 45, 111-136.

36. Schön, I.; Martens, K.; Dijk, P. Lost Sex. The Evolutionary Biology of Parthenogenesis; Springer: Berlin/Heidelberg, Germany, 2009; pp. 1-615.

37. Pilato, G.; Binda, M.G. Biogeography and limno-terrestrial tardigrades: Are they truly incompatible binomials? Zool. Anz. 2001, 240,511-516. [CrossRef]

38. Guil, N.; Sánchez-Moreno, S.; Machordom, A. Local biodiversity patterns in micrometazoans: Are tardigrades everywhere? Syst. Biodivers. 2009, 7, 259-268. [CrossRef]

39. Faurby, S.; Jorgensen, A.; Kristensen, R.M.; Funch, P. Distribution and speciation in marine intertidal tardigrades: Testing the roles of climatic and geographical isolation. J. Biogeogr. 2012, 39, 1596-1607. [CrossRef]

40. Gasiorek, P.; Vončina, K.; Michalczyk, Ł. Echiniscus testudo (Doyère, 1840) in New Zealand: Anthropogenic dispersal or evidence for the 'Everything is Everywhere' hypothesis? N. Z. J. Zool. 2019, 46, 174-181.

41. Doyère, P.L.N. Memoire sur les Tardigrades. Ann. Sci. Nat. Zool. Paris Ser. 2 1840, 14, $269-362$.

42. Stec, D.; Smolak, R.; Kaczmarek, Ł.; Michalczyk, Ł. An integrative description of Macrobiotus paulinae sp. nov. (Tardigrada: Eutardigrada: Macrobiotidae: Hufelandi group) from Kenya. Zootaxa 2015, 4052, 501-526. [CrossRef]

43. Beasley, C.W. The Phylum Tardigrada, 3rd ed.; Ramazzotti, G., Maucci, W., Eds.; English Translation; Clark Beasley: Abilene, TX, USA, 1995; pp. 1-1014.

44. Pilato, G.; Binda, M.G. Definition of families, subfamilies, genera and subgenera of the Eutardigrada, and keys to their identification. Zootaxa 2010, 2404, 1-52. [CrossRef]

45. Kaczmarek, Ł.; Michalczyk, Ł. The Macrobiotus hufelandi group (Tardigrada) revisited. Zootaxa 2017, 4363, 101-123. [CrossRef]

46. Kaczmarek, Ł.; Cytan, J.; Zawierucha, K.; Diduszko, D.; Michalczyk, Ł. Tardigrades from Peru (South America), with descriptions of three new species of Parachela. Zootaxa 2014, 3790, 357-379. [CrossRef]

47. Pilato, G. Analisi di nuovi caratteri nello studio degli Eutardigradi. Animalia 1981, 8, 51-57.

48. Michalczyk, Ł.; Kaczmarek, Ł. The Tardigrada Register: A comprehensive online data repository for tardigrade taxonomy. J. Limnol. 2013, 72, 175-181. [CrossRef]

49. Bertolani, R.; Guidetti, R.; Marchioro, T.; Altiero, T.; Rebechci, L.; Cesari, M. Phylogeny of Eutardigrada: New molecular data and their morphological support lead to the identification of new evolutionary lineages. Mol. Phylogenetics Evol. 2014, 76, 110-126. [CrossRef] [PubMed]

50. Perry, E.; Miller, W.R.; Kaczmarek, Ł. Recommended abbreviations for the names of genera of the phylum Tardigrada. Zootaxa 2019, 4608, 145-154. [CrossRef] [PubMed]

51. Nederström, P. Die bis jetzt aus Finland bekannten Tardigraden. Acta Soc. Fauna Flora Fenn. 1919, 46, 1-25.

52. Dastych, H. The Tardigrada from Antarctica with description of several new species. Acta Zool. Cracov. 1984, 27, 377-436.

53. Pilato, G. The taxonomic value of the structures for the insertion of the stylet muscles in the Eutardigrada, and description of a new genus. Zootaxa 2013, 3721, 365-378. [CrossRef]

54. Pilato, G.; Binda, M.G. Acutuncus, a new genus of Hypsibiidae (Eutardigrada). Entomol. Mitt. Zool. Mus. Hamburg 1997, 12, 159-162.

55. Casquet, J.; Thebaud, C.; Gillespie, R.G. Chelex without boiling, a rapid and easy technique to obtain stable amplifiable DNA from small amounts of ethanol-stored spiders. Mol. Ecol. Resour. 2012, 12, 136-141. [CrossRef] 
56. Sands, C.J.; Mcinnes, S.J.; Marley, N.J.; Goodall-Copestake, W.P.; Convey, P.; Linse, K. Phylum Tardigrada: An “individual” approach. Cladistics 2008, 24, 861-871. [CrossRef]

57. Mironov, S.V.; Dabert, J.; Dabert, M. A new feather mite species of the genus Proctophyllodes Robin, 1877 (Astigmata: Proctophyllodidae) from the long-tailed tit Aegithalos caudatus (Passeriformes: Aegithalidae): Morphological description with DNA barcode data. Zootaxa 2012, 3253, 54-61. [CrossRef]

58. Folmer, O.; Black, M.; Hoeh, W.; Lutz, R.; Vrijenhoek, R. DNA primers for amplification of mitochondrial cytochrome c oxidase subunit I from diverse metazoan invertebrates. Mol. Mar. Biol. Biotechnol. 1994, 3, 294-299. [PubMed]

59. Untergasser, A.; Cutcutache, I.; Koressaar, T.; Ye, J.; Faircloth, B.C.; Remm, M.; Rozen, S.G. 2012. Primer3-New capabilities and interfaces. Nucleic Acids Res. 2012, 40, e115. [CrossRef] [PubMed]

60. Altschul, S.F.; Gish, W.; Miller, W.; Myers, E.W.; Lipman, D.J. Basic local alignment search tool. J. Mol. Biol. 1990, 215, 403-410. [CrossRef]

61. Thompson, J.D.; Higgins, D.G.; Gibson, T.J. CLUSTAL W: Improving the sensitivity of progressive multiple sequence alignment through sequence weighting, positionspecific gap penalties and weight matrix choice. Nucleic Acids Res. 1994, 22, 4673-4680. [CrossRef] [PubMed]

62. Hall, T.A. BioEdit: A user-friendly biological sequence alignment editor and analysis program for Windows 95/98/NT. Nucleic Acids Symp. 1999, 41, 95-98.

63. Rice, P.; Longden, I.; Bleasby, A. EMBOSS: The European molecular biology open software suite. Trends Genet. 2000, 16, 276-277. [CrossRef]

64. Goujon, M.; Mcwilliam, H.; Li, W.; Valentin, F.; Squizzato, S.; Paern, J.; Lopez, R. A new bioinformatics analysis tools framework at EMBL-EBI. Nucleic Acids Res. 2010, 38, 695-699. [CrossRef]

65. Librado, P.; Rozas, J. DnaSP v5: A software for comprehensive analysis of DNA polymorphism data. Bioinformatics 2009, 25, 1451-1452. [CrossRef]

66. Roszkowska, M.; Stec, D.; Ciobanu, D.A.; Kaczmarek, Ł. (2016) Tardigrades from Nahuel Huapi National Park (Argentina, South America) with descriptions of two new Macrobiotidae species. Zootaxa 2016, 4105, 243-260. [CrossRef]

67. Morek, W.; Gąsiorek, P.; Stec, D.; Blagden, B.; Michalczyk, Ł. Experimental taxonomy exposes ontogenetic variability and elucidates the taxonomic value of claw configuration in Milnesium Doyère, 1840 (Tardigrada: Eutardigrada: Apochela). Contrib. Zool. 2016, 85, 173-200. [CrossRef]

68. Kaczmarek, Ł.; Grobys, D.; Kulpa, A.; Bartylak, T.; Kmita, H.; Kepel, M.; Kepel, A.; Roszkowska, M. Two new species of the genus Milnesium Doyère, 1840 (Tardigrada, Apochela, Milnesiidae) from Madagascar. ZooKeys 2019, 884, 1-22. [CrossRef] [PubMed]

69. Morek, W.; Stec, D.; Gąsiorek, P.; Surmacz, B.; Michalczyk, Ł. Milnesium tardigradum Doyère, 1840: The first integrative study of inter-population variability in a tardigrade species. J. Zool. Syst. Evol. Res. 2019, 57, 1-23. [CrossRef]

70. Surmacz, B.; Morek, W.; Michalczyk, Ł. What if multiple claw configurations are present in a sample: A case study with the description of Milnesium pseudotardigradum sp. nov. with unique developmental variability. Zool. Stud. 2019, 58, 32.

(C) 2020 by the authors. Licensee MDPI, Basel, Switzerland. This article is an open access article distributed under the terms and conditions of the Creative Commons Attribution (CC BY) license (http://creativecommons.org/licenses/by/4.0/). 